Bull. Chem. Soc. Ethiop. 2007, 21(1), 39-61.

ISSN 1011-3924

Printed in Ethiopia

(c) 2007 Chemical Society of Ethiopia

\title{
COMPARISON OF AUTHIGENIC MINERALS IN SANDSTONES AND INTERBEDDED MUDSTONES, SILTSTONES AND SHALES, EAST BERLIN FORMATION, HARTFORD BASIN, USA
}

\author{
Wolela Ahmed \\ Department of Petroleum Operations, Ministry of Mines, P.O. Box 486, Addis Ababa, Ethiopia
}

(Received November 28, 2005; June 19, 2006)

\begin{abstract}
The East Berlin formation consists mainly of alternating sequences of fluviatile, lacustrine and playa sediments. Diagenetic sequences reconstruction revealed the same range of authigenic minerals in the studied sandstones and the interbedded fine-grained sediments (mudstones and siltstones). This indicates that the diagenetic processes that took place in the sandy facies also took place in fine-grained sediments. Mechanically infiltrated clays, graincoating clay/hematite, quartz and feldspar overgrowths, carbonate cements and pore-filling and pore-lining clay minerals that precipitated in the sandy facies also precipitated in the fine-grained sediments. The abundance of authigenic minerals in decreasing order include: sandstone > siltstone $>$ mudstone $>$ shale. Except minor amounts of authigenic illite-smectite and illite, the shaly facies dominated by detrital clay, carbonate, quartz and feldspars framework grains. Authigenic minerals such as quartz, albite and K-feldspar are absent in the shaly facies, possibly related to early destruction of porosity. The lacustrine sandstones, siltstones and mudstones followed marine diagenetic trend, whereas playa and fluviatile sandstones, siltstones and mudstones followed red bed diagenetic trend. Mechanically compacted mudstones, siltstones and shales expelled large volume of mineralized pore water, which might migrated into the sandstonerich section. Part of the ions for the precipitation of quartz overgrowths and carbonate cements in the sandy facies possibly contributed from the interbedded siltstones, mudstones and shales facies.
\end{abstract}

KEY WORDS: Authigenic minerals, Mudstone, Sandstone, Siltstone, East Berlin formation, Hartford Basin

\section{INTRODUCTION}

The East Berlin formation consists mainly of alternating sequences of fluviatile, lacustrine and playa sediments [1]. The formation was considered for case studies to understand the diagenetic minerals in fluviatile, playa and lacustrine sandstones and the interbedded fine-grained sediments whether they follow the same or different diagenetic trends. The major factors which control diagenesis of sandstone and other clastic sediments include: temperature, pore water chemistry, fluid flow, mineralogical partitioning, depositional environment, tectonic setting, time, depth of burial and time of uplift, geothermal gradient and subsurface pressure [2, 3]. Therefore, reconstruction of the diagenetic history of authigenic minerals in sandstone and finegrained sediments is vital in understanding porosity and permeability to predict the reservoir characteristics of sandstones. The types of minerals formed during sandstones and other clastics diagenesis have direct effect on reservoir characteristics. Mechanically infiltrated clays, authigenic clay minerals, feldspar overgrowths, quartz overgrowths, carbonates and hematite cements have direct control on the reservoir characteristics of the studied sandstone and interbedded fine-grained clastics. The study is needed to understand the abundance and the distribution of diagenetic minerals in sandstones and fine-grained sediments. The main objective of this paper is to study different types of authigneic minerals in different depositional environments and understand their effects on reservoir characteristic in sandstones and finegrained sediments.

*Corresponding author. E-mail: wolela_am@yahoo.com 
Fluviatile and playa sediments (red sandstones, siltstones and mudstones) experienced redbed diagenesis, whereas the lacustrine sediments (grey mudstones, sandstones and black shales) experienced diagenesis typical of marine mudstones and sandstones [4-7]. The type of mineralized pore water released from the fine-grained sediments has a significant influence on the trends of sandstone diagenesis. Mechanically compacted mudstones, siltstones and shales expelled large volume of mineralized pore water, which might migrated into the sandstone-rich section [8-12].

Based on textural relationships, fluid inclusions, burial and thermal histories and mineralfilled pore spaces, the following paragenetic sequences are reconstructed for the fluvial (subaerially-exposed) sandstones in the Hartford Basin: (1) mechanically infiltrated clay, (2) concretionary calcite, (3) mechanical compaction, (4) grain dissolution, (5) grain coating, (6) feldspar overgrowths, (7) quartz overgrowths, (8) basalt eruption, (9) carbonate cementation, (10) cement and unstable grain dissolution, (11) kaolinite precipitation, (12) hematite cementation, (13) illite cementation, (14) chlorite cementation, (15) authigenesis of euhedral quartz, and (16) hydrocarbon migration; pyrite and apatite precipitation $[1,7,12]$.

Lacustrine (subaqueous) sandstones exhibit a different paragenetic sequence in the Hartford Basin: (1) pyrite precipitation, (2) concretionary dolomite, (3) grain dissolution, (4) grain coating clays, (5) feldspar overgrowths, (6) quartz overgrowths, (7) basalt eruption, (8) carbonate cementation, (9) mechanical compaction, (10) cements and unstable grain dissolution, (11) smectite-chlorite, (12) illite cementation, (13) chlorite cementation, (14) authigenesis of euhedral crystals of quartz, and (15) hydrocarbon migration; pyrite and apatite precipitation [7].

Conventional petrographic microscopy, scanning electron microscopy, and electron microprobe can provide information about authigenic minerals in sandstones and fine-grained sediments. Scanning electron microscope (SEM) studies provide information to identify and differentiate authigenic minerals. SEM also provides essential information about the paragenetic sequence of the authigenic minerals. Back-scattered probe analyses gives a significant amount of information about the distribution, abundance and the textural relationship of the authigenic minerals, and also help to differentiate (i) authigenic albite from detrital plagioclase, (ii) authigenic K-feldspar from detrital K-feldspar.

\section{EXPERIMENTAL}

In order to understand the abundance of authigenic minerals, integrated studies were carried out on conventional petrographic microscope, electron microprobe (EMP) and scanning electron microscope (SEM). The diagenetic sequences for the sandstones and other fine-grained clastics were reconstructed from conventional petrographic microscopy, scanning electron microscopy and microprobe studies. The paragenetic sequences are reconstructed based on the textural relationship of the authigenic minerals, burial history and fluid inclusions studies. Resinimpregnated thin sections were examined using conventional petrographic microscope, and their modal composition evaluated by counting 300 points.

Unpolished gold-coated chip samples were examined under a JEOL 6400 scanning electron microscope equipped with energy dispesive X-ray analysis (EDX) system with accelerating voltage $10-15 \mathrm{kV}$, to identify morphology of authigenic minerals, mineral composition and their textural relationships.

Polished carbon-coated chips and thin sections were examined under a JEOL 733 superprobe with an accelerating voltage of $15 \mathrm{kV}$, to identify the mineralogical composition, textural relationships and zoning in authigenic minerals. A ZAF software programme was used to calculate weight percentage of oxides in each spot analysis. The textural and stratigraphic position of the authigenic minerals plus weight percentage oxide calculations data allowed to 
compare the diagenetic trends between sandstones and interbedded siltstones, mudstones and shales.

Fluid inclusion microthermometric measurements were conducted on a petrographic microscope equipped with a Linkam THM 600 microthermometric stage linked with a CS 196 cooling system. A Pr 600 temperature controller was mounted on a Nikon OPTIPHOT2. POL microscope. Imaging was accomplished with a TMC 516 color CCD camera and Hitachi highresolution monitor with superlong distance lenses of 40x and 60x. The heating-freezing stage was calibrated from -160 to $300{ }^{\circ} \mathrm{C}$. Both sides of polished slices and quartz crystals were examined.

\section{Background geology of the Hartford Basin}

The Hartford basin is a half-graben about $150 \mathrm{~km}$ long and up to $30 \mathrm{~km}$ across [13]. The basin is developed by crustal extension associated with the breaking up of Pangea and the opening of the Atlantic Ocean [14-16]. The basin is in-filled with $4500-5000 \mathrm{~m}$ thick clastic sediments including alluvial fans, fluviatile, playa red beds, lacustrine grey and black strata, and extrusive tholeiitic basalts [1, 7, 17-19; Figures 1 and 2].

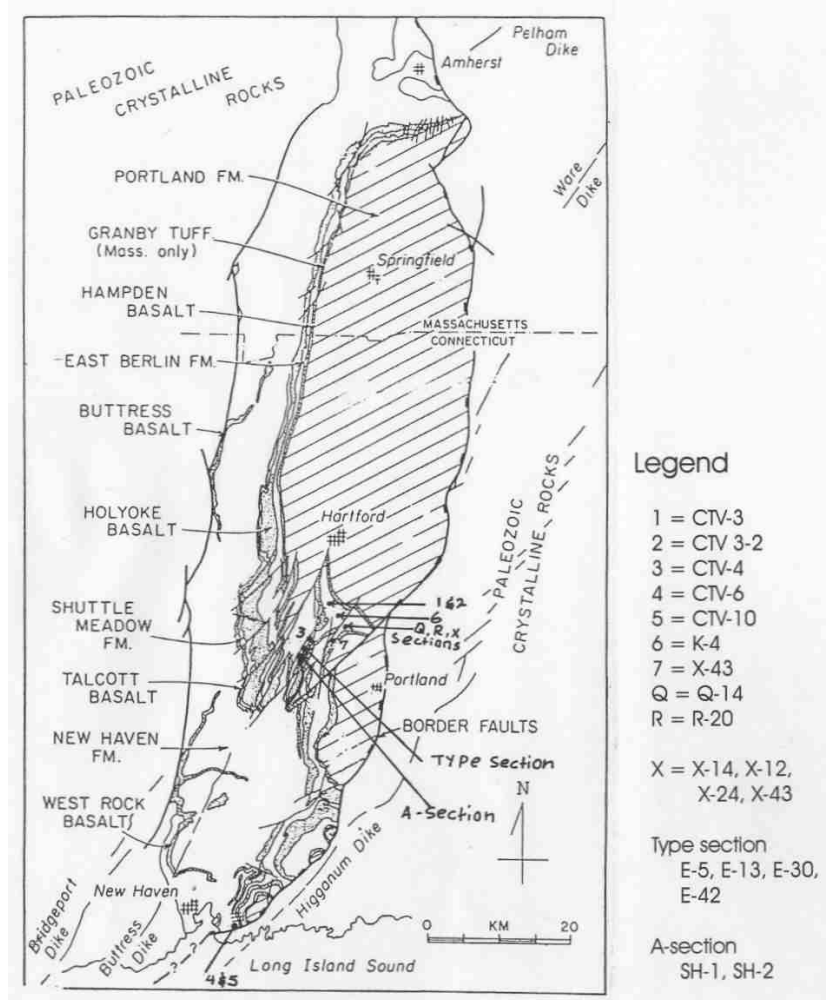

Figure 1. Geological map of the Hartford Basin (after Hubert et al. [18]) and sample location map of studied areas in the Hartford Basin.

During initial subsidence in the Upper Triassic, rivers flowed from both sides of the Hartford Basin deposited the New Haven Arkose. The $2 \mathrm{~km}$ thick alluvial fan and fluvial red

Bull. Chem. Soc. Ethiop. 2007, 21(1) 
bed-dominated New Haven Arkose was deposited when the rate of sedimentation exceeded the rate of basin subsidence [18]. Fluvatile, lacustrine and playa-dominated Shuttle Meadow and the East Berlin formations were deposited when the subsidence rate increased to exceed the rate of sedimentation [18].

The $65 \mathrm{~m}$ thick Talcot Basalt separated the New Haven Arkose from the Shuttle Meadow formation. The Talcot Basalt dated to be $187+10 \mathrm{Ma}$ [20]. Sedimentation returned in the basin after the Talcot Basalt eruption to deposit $150 \mathrm{~m}$ thick fluviatile, lacustrine and playa dominated Shuttle Meadow formation [19 and 21].

The $100 \mathrm{~m}$ thick Holyoke Basalt separated the Shuttle Meadow formation and East Berlin formation. Sedimentation continued in the basin to deposit the East Berlin formation after the Holyoke Basalt eruption. Gierlowski-Kordesch and Rust [1] classified the East Berlin formation into eight major facies. These include: trough cross-stratified sandstone (St), ripple crosslaminated siltstone (Fr), horizontally stratified sandstone $(\mathrm{Sh})$, interbedded sandstones and mudrocks $(\mathrm{Sf})$, black shale $\left(\mathrm{Fl}_{1}\right)$, Stratified mudstones $\left(\mathrm{Fl}_{2}\right)$, disrupted shale $\left(\mathrm{Fl}_{3}\right)$, and disrupted mudstone (Fm).

The $60 \mathrm{~m}$ thick Hampden Basalt eruption interrupted sedimentation of the East Berlin formation. The Hampden Basalt found between the East Berlin formation and the $2 \mathrm{~km}$ thick alluvial fan and fluviatile-dominated Portland Formations. The NE-SW trending normal faults cut the basin-fill through the Portland Formation, so that the last movements on them post-dated sedimentation $[22,23]$.

\begin{tabular}{|c|c|c|c|c|c|c|}
\hline Era & Period & Formation & $\begin{array}{l}\begin{array}{l}\text { Lith- } \\
\text { ology }\end{array} \\
\end{array}$ & \begin{tabular}{|l|} 
Maximum \\
Thickness \\
in $(\mathrm{m})$
\end{tabular} & $\begin{array}{l}\text { Lithology and } \\
\text { environment }\end{array}$ & $\begin{array}{l}\text { Hydrocarbon } \\
\text { plays }\end{array}$ \\
\hline \multirow{7}{*}{ 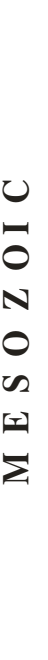 } & \multirow{6}{*}{ 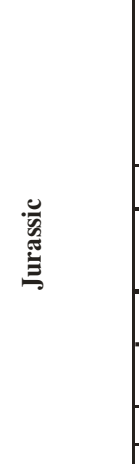 } & Portlandian & & 2000 & $\begin{array}{l}\text { Alluvial fan and } \\
\text { fluviatile sandy } \\
\text { conglomerate, } \\
\text { sandstone and } \\
\text { siltstone }\end{array}$ & Reservoir \\
\hline & & Hampden Basalt & & 60 & & Seal \\
\hline & & East Berlin & & 170 & $\begin{array}{l}\text { Fluvatile, } \\
\text { lacustrine and } \\
\text { playa sediments }\end{array}$ & $\begin{array}{l}\text { Reservoir, } \\
\text { source and } \\
\text { seal }\end{array}$ \\
\hline & & Holyoke Basalt & & 100 & & Source \\
\hline & & Shuttle Meadow & & 150 & $\begin{array}{l}\text { Fluvatile, } \\
\text { lacustrine and } \\
\text { playa sediments }\end{array}$ & $\begin{array}{l}\text { Reservoir, } \\
\text { source and } \\
\text { seal }\end{array}$ \\
\hline & & Talcot Basalt & & 65 & & Seal \\
\hline & 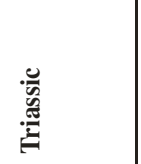 & New Haven Arkose & & 2000 & $\begin{array}{l}\text { Alluvial fan and } \\
\text { fluviatile sandy } \\
\text { conglomerate, } \\
\text { sandstone and } \\
\text { siltstone }\end{array}$ & Reservoir \\
\hline P R E & A M B R I A N & Basement rocks & & & & \\
\hline
\end{tabular}

Figure 2. Chrono-lithostratigraphic section, depositional environments and hydrocarbon plays of the Hartford Basin.

Bull. Chem. Soc. Ethiop. 2007, 21(1) 


\section{RESULTS AND DISCUSSION}

\section{Diagenetic minerals}

Based on conventional petrographic microscope, scanning electron microscope, microprobe microscope, burial history and fluid inclusions the following paragenetic sequences were established from the textural, stratigraphic relationships and fluid inclusion studies of authigenic minerals in sandstone, siltstone and mudstone. The distribution of authigenic minerals in the sandy, silty, muddy and shaly facies in fluviatile, playa and lacustrine environments are given in Figures 3-5 and Tables 1, 8-10.

Mechanically infiltrated clays. Mechanically infiltrated clay is widely observed in the studied sediments, and considered to be the earliest facies-related minerals. Mechanical infiltrated clays are found in fluviatile sediments, and dominated by smectite and illite-smectite (Figure 7f). SEM studies confirmed the presence of cutans around the detrital framework grains. In places, the primary porosity in the sandy, silty and muddy facies is highly reduced by infiltrated clay. In late-stage diagenesis, mechanically infiltrated clay transformed to authigenic clay minerals (illite and chlorite). Rock with abundant infiltrated clay had a restricted diagenetic evolution. Mechanically infiltrated clay is introduced with meteoric water in the depositional environments $[24,25]$. The non-crystalline form indicates their detrital origin.

Authigenesis of concretionary calcite. This is one of the earliest facies-related minerals in the fluviatile and playa mudstone, siltstone and sandstone facies. Concretions were precipitated in the intergranular pore spaces by pedogenic processes. The concretions are unevenly distributed in the sandy, silty and muddy facies. Concretions are more abundantly distributed in the sandy facies comparing to the silty and muddy facies (Table 5). Calcrete develop in poorly drained areas in semi-arid to arid environments [26, 27].
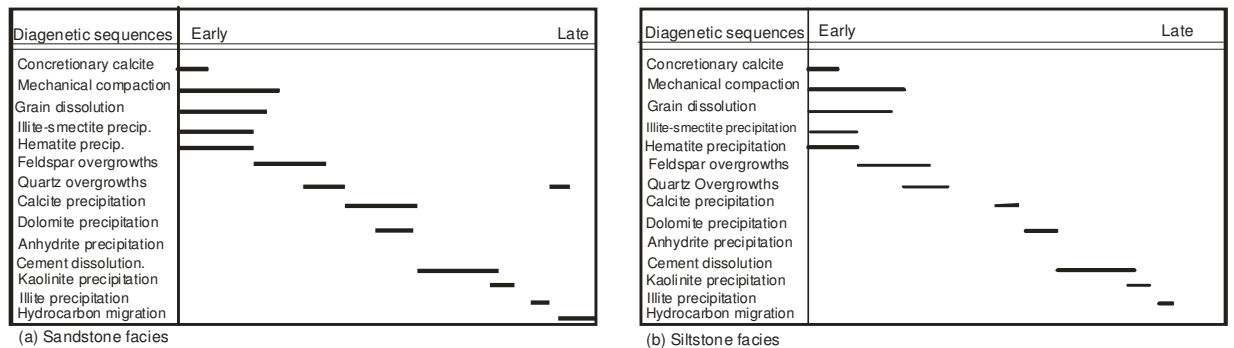

(a) Sandstone facies

(b) Siltstone facies
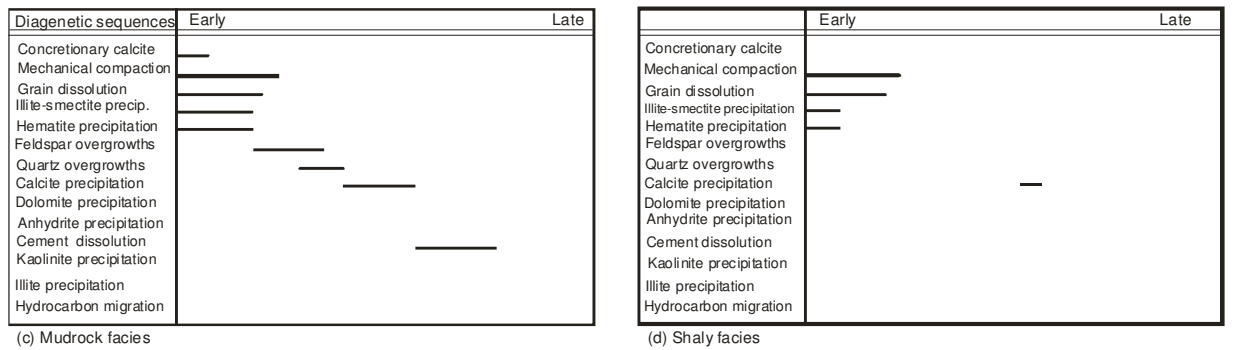

Figure 3. Diagenetic sequences of playa and fluviatile sandstones and the interbedded silty, muddy and shaly facies.

Bull. Chem. Soc. Ethiop. 2007, 21(1) 


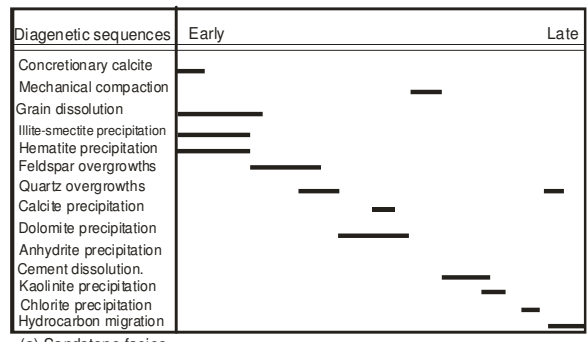

(a) Sandstone facies

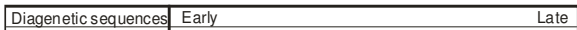

\section{Concretionary calcite} Mechanical compaction Grain dissolution Illite-smectite precip. Hematite precip.
Feldspar overgrow Quartz overgrowths Dolomite precip. Anhydrite precip. Cement \& grain dis Kaolinite precip. Chlorite precip. Hydrocarbon migration

(c) Mudstone facies

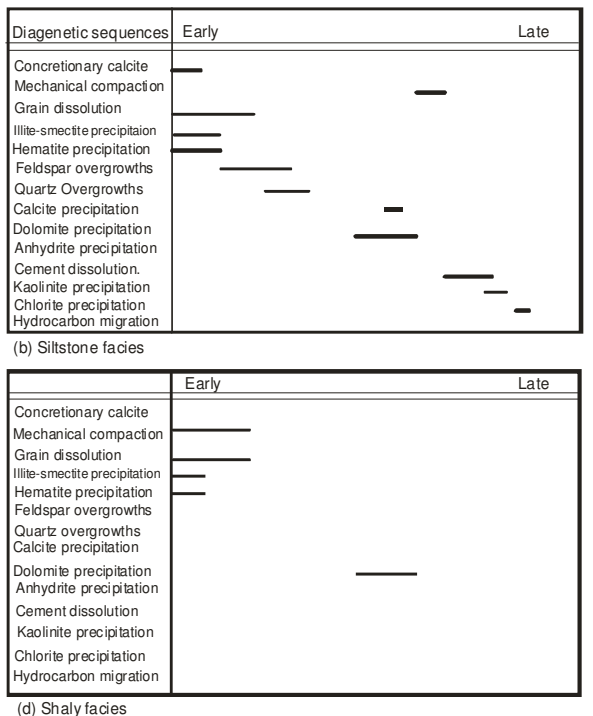

Figure 4. Diagenetic sequences of lacustrine sandstones and the interbedded silty, muddy and shaly facies.

Dissolution of unstable minerals. Carbonic acid formed when meteoric water interacts with $\mathrm{CO}_{2}$ in the air. Dissolution of unstable minerals is a continuous process during diagenesis. Dissolution of unstable minerals by acidic meteoric pore water is the possible driving force for the precipitation of authigenic minerals in the diagenetic environments [6, 28, 29]. In rift basins, gravity-deriven meteoric water flow can penetrate at least several kilometres into the sedimentary basin. Percolation of acidic pore water in the diagenetic environment facilitated dissolution of feldspars and ferromagnesian minerals and released ions of potassium, sodium, aluminium, silicon, calcium, magnesium and iron. Meteroric water plays major role in transport of dissolved ions from areas of high concentration to areas of low concentration.

$$
\begin{aligned}
& \mathrm{CaAl}_{2} \mathrm{SiO}_{8} \text { (calcic plagioclase) }+2 \mathrm{CO}_{2}+3 \mathrm{H}_{2} \mathrm{O}=\mathrm{Al}_{2} \mathrm{Si}_{2} \mathrm{O}_{5}(\mathrm{OH})_{4}+\mathrm{Ca}^{2+}+2 \mathrm{HCO}_{3}^{-} \\
& 2 \mathrm{KAlSi}_{3} \mathrm{O}_{8} \text { (K-feldspar) }+2 \mathrm{H}^{+}+\mathrm{H}_{2} \mathrm{O}=\mathrm{Al}_{2} \mathrm{Si}_{2} \mathrm{O}_{5}(\mathrm{OH})_{4}+4 \mathrm{SiO}_{2}+2 \mathrm{~K}^{+} \\
& \mathrm{NaAlSi}_{3} \mathrm{O}_{8} \text { (albite) }+8 \mathrm{H}_{2} \mathrm{O}=\mathrm{Na}^{+}+3 \mathrm{Si}(\mathrm{OH})_{4}+\mathrm{Al}^{3+}+4 \mathrm{OH}^{-} \\
& 2 \mathrm{NaAlSi}_{3} \mathrm{O}_{8} \text { (albite) }+2 \mathrm{CO}_{2}+11 \mathrm{H}_{2} \mathrm{O}=\mathrm{Al}_{2} \mathrm{Si}_{3} \mathrm{O}_{5}(\mathrm{OH})_{4}+2 \mathrm{Na}^{+}+2 \mathrm{HCO}_{3}^{-}+4 \mathrm{H}_{4} \mathrm{SiO}_{4} \\
& \mathrm{Mg}_{2} \mathrm{SiO}_{4} \text { (olivine) }+4 \mathrm{H}_{2} \mathrm{O}=2 \mathrm{Mg}^{2+}+4 \mathrm{OH}+\mathrm{Si}(\mathrm{OH})_{4}
\end{aligned}
$$

Mechanical compaction. Mechanical compaction took place at early stage of diagenesis in the fluviatile and playa sandy, silty and muddy facies. Mechanical compaction in the fluviatile and playa fine-grained sediments might have introduced mineralized pore water from the muddy and silty facies into the sandy facies at an early stage of diagenesis. Carbonate and albite cements extensively cemented the lacustrine mudstones, siltstones and sandstones indicating that cementation took place prior to mechanical compaction. Mechanically compacted siltstones, mudstones and shales expelled large volume of mineralized pore water, which migrated into sandstone-rich section in the basin. 
Table 1. Diagenetic sequences of fluvatile and lacustrine sediments, East Berlin formation.

\begin{tabular}{|c|c|c|}
\hline Fluviatile sediments & Lacustrine sediments & Zone \\
\hline $\begin{array}{l}\text { (1) Influx of gravity-driven acidic } \\
\text { metoric, water intiated dissolution of } \\
\text { unstable, grains and provided ions of } \\
\text { potassium, sodium, aluminium, } \\
\text { calcium, magnesium and iron }\end{array}$ & $\begin{array}{l}\text { (1) Influx of gravity-driven acidic metoric, } \\
\text { water intiated dissolution of unstable, grains } \\
\text { and provided ions of potassium, sodium, } \\
\text { aluminium, calcium, magnesium and iron }\end{array}$ & \\
\hline (2) Precipitation of concretion & (2) Precipitation of concretion & \\
\hline (3) Mechanical compaction & (3) Precipitation of pyrite & $\begin{array}{l}\text { Sulphate } \\
\text { reducing zone }\end{array}$ \\
\hline $\begin{array}{l}\text { (4) Precipitation of grain-coating } \\
\text { clays }\end{array}$ & (4) Precipitation of grain-coating clays & \\
\hline (5) Feldspar overgrowths & (5) Feldspar overgrowth & \\
\hline (6) Quartz overgrowths & (6) Quartz overgrowths & \\
\hline (7) Carbonate precipitation & (7) Carbonate precipitation & $\begin{array}{l}\text { Fermentation } \\
\text { zone }\end{array}$ \\
\hline $\begin{array}{l}\text { (8) Mature source rocks, and clay } \\
\text { minerals transformation } \\
\text { released carbon dioxide and react } \\
\text { with water to form acidic pore } \\
\text { water }\end{array}$ & (8) Mechanical compaction & \\
\hline $\begin{array}{l}\text { (9) Dissolution of carbonate by } \\
\text { acidic pore water }\end{array}$ & $\begin{array}{l}\text { (9) Mature source rocks, clay minerals } \\
\text { transformation released } \mathrm{CO}_{2} \text { and react with } \\
\text { water to form acidic pore water }\end{array}$ & $\begin{array}{l}\text { Decarboxylation } \\
\text { zone }\end{array}$ \\
\hline $\begin{array}{l}\text { (10) Precipitation of pore-filling } \\
\text { clays }\end{array}$ & $\begin{array}{l}\text { (10) Dissolution of carbonate cements by } \\
\text { acidic pore water }\end{array}$ & \\
\hline \multirow{2}{*}{$\begin{array}{l}\text { (11) Oil emplacement in fluviatile } \\
\text { sandstone }\end{array}$} & (11) Precipitation of pore-filling clays & \\
\hline & $\begin{array}{l}\text { (12) Oil emplacement and precipitation of } \\
\text { pyrite and apatite }\end{array}$ & $\begin{array}{l}\text { Oil generation } \\
\text { zone }\end{array}$ \\
\hline
\end{tabular}

Pyrite precipitation. SEM and probe studies confirmed the presence of pyrite crystals (Figure 6a). Pyrite crystals range from 1 to $30 \mu \mathrm{m}$ in the silty and muddy facies and 10 to $100 \mu \mathrm{m}$ in the sandy facies. Pyrite is the earliest diagenetic mineral in the lacustrine grey mudstone, siltstone and sandstone facies. Pyrite is found only in the lacustrine sediments, and formed at an early stage of diagenesis in the sulphate-reducing zone below the sediment-water interface [5]. Pyrite crystals mainly occur as disseminated patches. However, pyrite crystals are also found along the bedding planes and lamination. The presence of pyrite is an indicator of anoxic environment. Late-stage diagenetic pyrite crystals are identified in the sandy facies associated with bitumen. Minor amounts of apatite are also identified in bitumen-bearing sandstones.

$$
15 \mathrm{CH}_{2} \mathrm{O}+2 \mathrm{Fe}_{2} \mathrm{O}_{3}+8 \mathrm{SO}_{4}{ }^{2-}=4 \mathrm{FeS}_{2}(\text { pyrite })+\mathrm{H}_{2} \mathrm{O}+15 \mathrm{HCO}_{3}{ }^{-}+\mathrm{OH}^{-}
$$



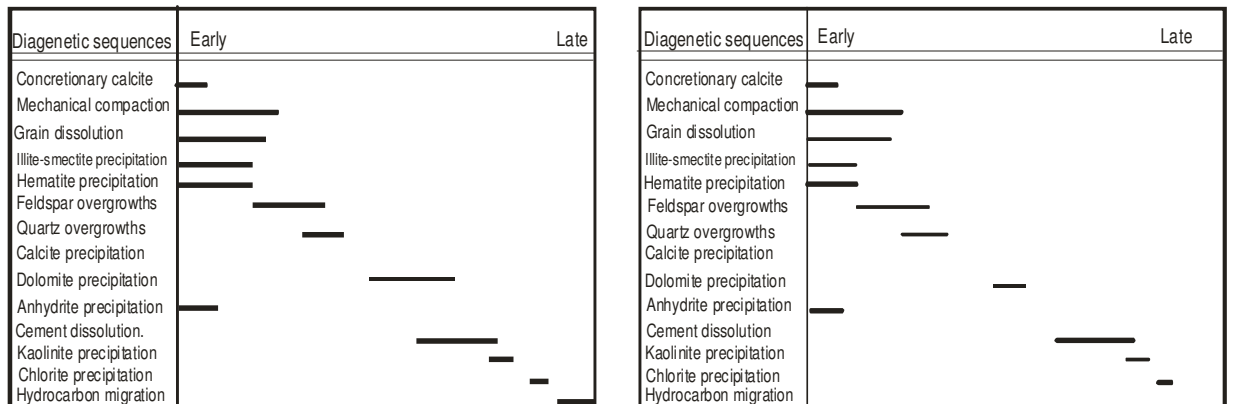

(a) Sandstc

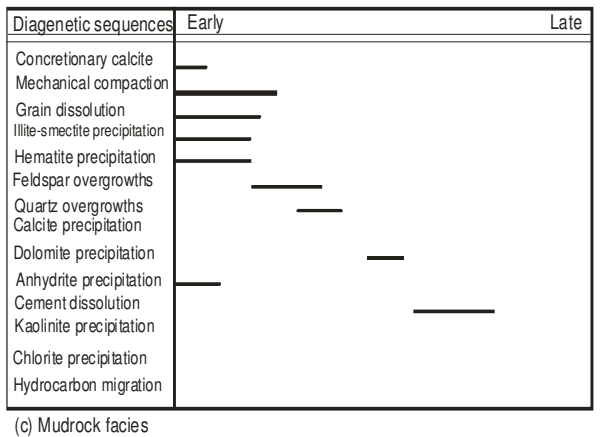

(b) Siltstonet

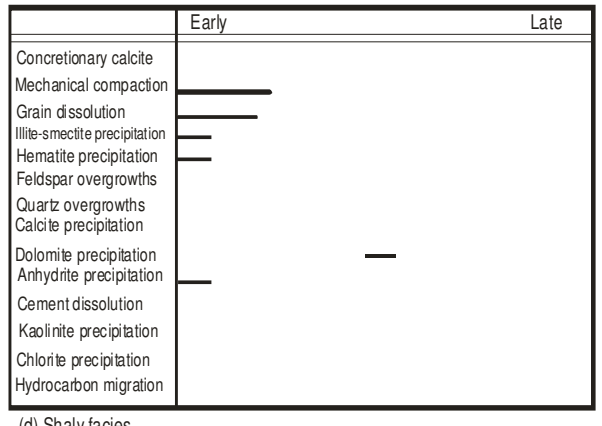

Figure 5. Diagenetic sequences of playa sandstones and the interbedded silty, muddy and shaly facies.

Authigenesis of clay minerals. Clay minerals exist as grain-coating, pore-lining and pore-filling cements (Figure 6d and f). Grain-coating clays are one of the earliest authigenic minerals in the studied fluvatile, playa and lacustrine mudstone, siltstone and sandstone facies.

SEM studies indicate the presence of smectite-chlorite in the playa sandy, muddy and silty facies. Illite is the predominant clay mineral in fluviatile sequences (Figure 6d), whereas the lacustrine sandstones, siltstones and mudstones are dominated by minor amounts of box-work illite-smectite and box-work to rosette smectite-chlorite (Figure 6d). Microprobe analyses revealed the presence of potassium, magnesium, calcium, silicon, aluminium and iron, indicating illite-smectite and smectite-chlorite.

The lower abundance of authigenic clay minerals in the lacustrine sediments possibly indicates that the saline pore waters condition were not suitable for the authigenesis of clay minerals or related to albitization i.e. metasomatism in the expense of clay minerals and quartz [30].

Authigenesis of feldspar. Petrographic microscopy, SEM and probe studies confirmed the presence of feldspar overgrowths and euhedral crystals in the muddy, silty and sandy facies. Albite overgrowths are the predominant feldspar types. Authigenesis of feldspar overgrowths was commenced in the mid stage of diagenesis (Figures 3-5). The overgrowths range from 5 to $15 \mu \mathrm{m}$ in the sandy facies, and 1 to $8 \mu \mathrm{m}$ in the muddy and silty facies (Figures $6 \mathrm{~b}$ and c; $7 \mathrm{a}, \mathrm{b}$ and c). Microprobe weight percentage calculations on authigenic crystals of albite in the playa muddy facies revealed average compositions of $69.48 \% \mathrm{SiO}_{2}, 20.77 \% \mathrm{Al}_{2} \mathrm{O}_{3}$ and $9.74 \% \mathrm{Na}_{2} \mathrm{O}$, whereas authigenic crystals of albite in the playa sandy facies revealed average composition of

Bull. Chem. Soc. Ethiop. 2007, 21(1) 
$69.82 \% \mathrm{SiO}_{2}, 20.88 \% \mathrm{Al}_{2} \mathrm{O}_{3}$ and $9.64 \% \mathrm{Na}_{2} \mathrm{O}$ with minor impurities of $\mathrm{CaO}(0.395-3.2 \%)$ (Table 2). Microprobe weight percentage calculations of albite crystals in the lacustrine sandstones revealed average compositions of $68.74 \% \mathrm{SiO}_{2}, 20.82 \% \mathrm{Al}_{2} \mathrm{O}_{3}$ and $10.43 \% \mathrm{Na}_{2} \mathrm{O}$ (Table 2).
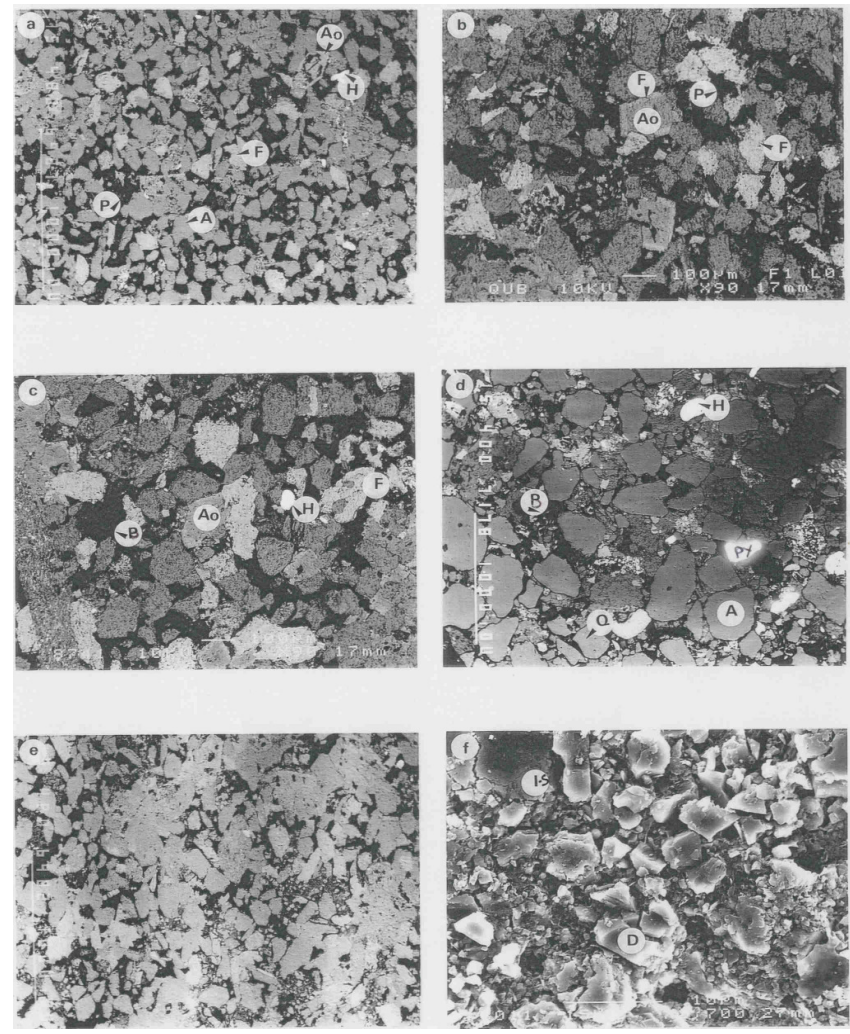

Figure 6. (a) Back-scattered photomicrograph showing pyrite crystals (Py) associated with feldspar grains in shallow lake sandstone (scale bar 10 microns). (b) Back-scattered photomicrograph showing feldspar grains (F), authigenic albite (Ao) and hematite/illite (H/I) in alluvial siltstone sample (scale bar 1000 microns). (c) SEM photomicrograph showing authigenic K-feldspar (Fo) in ripple cross-laminated alluvial siltstone (scale bar 10 microns). (d) SEM photomicrograph showing pore-filling albite crystals (Ao) and illite (I) in stratified mudstone sample (scale bar 1 micron). (e) SEM photomicrograph showing pore-filling calcite $(\mathrm{C})$ in ripple cross-laminated alluvial fan siltstone (scale bar 10 microns). (f) SEM photomicrograph showing pore-filling dolomite (D) and chlorite (Ch) in black shale sample (scale bar 1 micron).

Microprobe weight percentage calculations of authigenic K-feldspar crystals in the lacustrine muddy facies revealed average compositions of $63.96 \% \mathrm{SiO}_{2}, 19.4 \% \mathrm{Al}_{2} \mathrm{O}_{3}$ and $16.37 \% \mathrm{~K}_{2} \mathrm{O}$, Whereas K-feldspar crystals in the sandy facies revealed average compositions of $64.03 \% \mathrm{SiO}_{2}$, $19.44 \% \mathrm{Al}_{2} \mathrm{O}_{3}$ and $16.53 \% \mathrm{~K}_{2} \mathrm{O}$ with minor impurities of $\mathrm{Na}_{2} \mathrm{O}(0-1.02 \%)$ (Table 5). Authigenic $\mathrm{K}$-feldspar or albite overgrowths are absent in the shaly facies.

Bull. Chem. Soc. Ethiop. 2007, 21(1) 

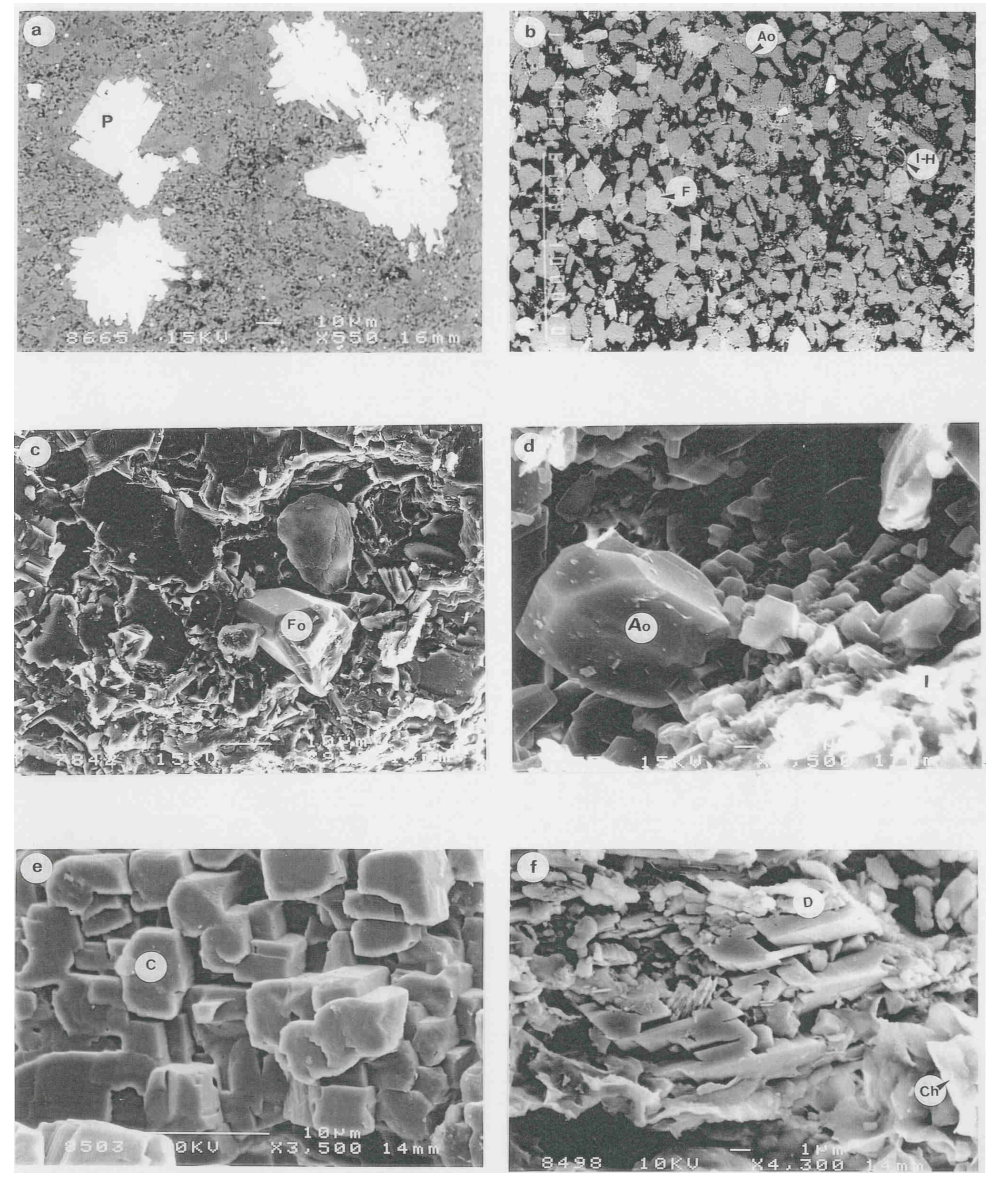

Figure 7. (a) Back-scattered photomicrograph showing albite grain (A), K-feldspar grains (F), albite overgrowths (Ao), porosity $(\mathrm{P})$ and hematite $(\mathrm{H})$ in alluvial/sandflat siltstone to interdedded sandstone sample (scale bar 1000 microns). (b) Back-scattered photomicrograph showing albitization $(\mathrm{Ao})$ of $\mathrm{K}$-feldspar $(\mathrm{F})$ and pore space $(\mathrm{P})$ in alluvial/sandflat trough cross-bedded sandstone sample (scale bar 100 microns). (c) Back-scattered photomicrograph showing K-feldspar (F) albite overgrowths (Ao), Hematite $(\mathrm{H})$ and porosity $(\mathrm{P})$ in alluvial/sandflat trough cross-bedded sandstone sample (scale bar 100 micron). (d) Back-scattered photomicrograph showing disintegration of iron-bearing grain, quartz $(\mathrm{Q})$, albite $(\mathrm{A})$, hematite $(\mathrm{H})$ and porosity (P) in alluvial plain cross-laminated siltstone to interbedded sandstone and mudstone sample (e) Back-scattered photomicrograph showing distributions of minerals, pore space and remnant floater dolomite cement in pore spaces in alluvial ripple crosslaminated siltstone sample (scale bar 1000 microns). (f) SEM photomicrograph showing extensive detrital dolomite (D) and detrital illite (I) in offshore lacustrine black shale (scale bar 1000 microns). 
Table 2. Microprobe analyses (\% composition) of authigenic albite (East Berlin formation).

$\mathrm{Ab}=$ albite, $\mathrm{Or}=$ orthoclase and $\mathrm{An}=$ anorthite.

\begin{tabular}{|c|c|c|c|c|c|c|c|c|c|}
\hline $\begin{array}{l}\text { Sample } \\
\text { No }\end{array}$ & Location & Lithology & $\mathrm{SiO}_{2}$ & $\mathrm{Al}_{2} \mathrm{O}_{3}$ & $\mathrm{CaO}$ & $\mathrm{Na}_{2} \mathrm{O}$ & $\begin{array}{c}\text { Average } \\
\mathrm{Ab}\end{array}$ & $\begin{array}{c}\text { Average } \\
\text { Or }\end{array}$ & $\begin{array}{c}\text { Average } \\
\text { An }\end{array}$ \\
\hline \multirow{9}{*}{ E-30 } & \multirow{9}{*}{ Playa } & \multirow{9}{*}{ Sandstone } & 65.14 & 23.09 & 2.47 & 9.29 & \multirow{9}{*}{99.9} & & \multirow{9}{*}{0.1} \\
\hline & & & 69.28 & 20.56 & & 10.16 & & & \\
\hline & & & 68.99 & 20.5 & & 10.51 & & & \\
\hline & & & 61.26 & 24.89 & 2.69 & 11.16 & & & \\
\hline & & & 65.49 & 22.84 & 3.2 & 8.47 & & & \\
\hline & & & 70.28 & 20.19 & & 9.53 & & & \\
\hline & & & 69.36 & 20.08 & & 10.55 & & & \\
\hline & & & 68.58 & 20.65 & & 10.77 & & & \\
\hline & & & 68.26 & 20.94 & 0.39 & 10.41 & & & \\
\hline \multirow{3}{*}{ Q-14 } & \multirow{3}{*}{ playa } & \multirow{3}{*}{$\begin{array}{l}\text { Mudstone/ } \\
\text { siltstone }\end{array}$} & 68.28 & 20.43 & & 11.29 & \multirow{3}{*}{99.6} & \multirow{3}{*}{0.1} & \multirow{3}{*}{0.3} \\
\hline & & & 69.79 & 20.44 & & 9.77 & & & \\
\hline & & & 70.38 & 21.46 & & 8.16 & & & \\
\hline \multirow{5}{*}{ E-5 } & \multirow{5}{*}{ Lacustrine } & \multirow{5}{*}{ Sandstone } & 69.86 & 20.83 & & 9.31 & \multirow{5}{*}{99.1} & & \multirow{5}{*}{0.9} \\
\hline & & & 70.34 & 20.75 & & 8.91 & & & \\
\hline & & & 68.99 & 22.03 & 0.68 & 8.31 & & & \\
\hline & & & 69.69 & 20.53 & & 9.77 & & & \\
\hline & & & 69.65 & 21.06 & & 9.29 & & & \\
\hline \multirow{3}{*}{ K-4 } & \multirow{3}{*}{ Fluviatile } & \multirow{3}{*}{ Sandstone } & 70.08 & 20.79 & & 9.14 & \multirow{3}{*}{98.8} & \multirow{3}{*}{0.4} & \multirow{3}{*}{0.8} \\
\hline & & & 69.76 & 21.69 & & 8.55 & & & \\
\hline & & & 68.58 & 20.68 & & 10.74 & & & \\
\hline \multirow{7}{*}{ CTV-4 } & \multirow{7}{*}{ Lacustrine } & \multirow{7}{*}{ Sandstone } & 67.87 & 20.75 & & 11.38 & \multirow{7}{*}{98} & \multirow{7}{*}{1} & \multirow{7}{*}{1} \\
\hline & & & 68.12 & 20.77 & & 11.12 & & & \\
\hline & & & 67.79 & 20.43 & & 11.78 & & & \\
\hline & & & 67.56 & 20.1 & & 12.35 & & & \\
\hline & & & 67.77 & 20.66 & & 11.57 & & & \\
\hline & & & 68.4 & 20.74 & & 10.86 & & & \\
\hline & & & 67.76 & 20.61 & & 11.63 & & & \\
\hline
\end{tabular}

Intergranular dissolution of unstable grains (feldspar and ferromagnesian) is the main source for the authigensis of K-feldspar and albite in the playa and lacustrine depositional environments. The abundance of albite cement in the playa and lacustrine sandstones, siltstones and mudstones indicates the abundance of aluminium, silicon and sodium ions in the pore waters. The lower abundance of K-feldspar overgrowths and crystals in the playa and lacustrine sediments might be related to albitization. When K-feldspar reacts with sodium ions, yield albite and released potassium ions [30]. The abundance of albite crystals (Figures 6d, 7b and c) in the sandy facies near the sandstone-siltstone and sandstone-mudstone contacts indicates pore water and mass transfer from the fine-grained sediments into the sandstone facies [10-12]. Feldspar overgrowths abundantly distributed in the sandy facies comparing to silty and muddy facies. 
Table 3. Microprobe analyses (\% composition) of detrital plagioclase feldspar (East Berlin formation, Hartford Basin). $\mathrm{Ab}=$ albite, $\mathrm{Or}=$ orthoclase and $\mathrm{An}=$ anorthite.

\begin{tabular}{|c|c|c|c|c|c|c|c|c|c|}
\hline $\begin{array}{l}\text { Sample } \\
\text { No }\end{array}$ & Location & Lithology & $\mathrm{SiO}_{2}$ & $\mathrm{Al}_{2} \mathrm{O}_{3}$ & $\mathrm{CaO}$ & $\mathrm{Na}_{2} \mathrm{O}$ & $\begin{array}{c}\text { Average } \\
\mathrm{Ab}\end{array}$ & $\begin{array}{c}\text { Average } \\
\text { Or }\end{array}$ & $\begin{array}{c}\text { Average } \\
\text { An }\end{array}$ \\
\hline \multirow{2}{*}{ E-30 } & \multirow{2}{*}{ Playa } & \multirow{2}{*}{ Sandstone } & 65.076 & 22.634 & 3.072 & 9.827 & \multirow{2}{*}{83.7} & \multirow{2}{*}{1.8} & \multirow{2}{*}{14.5} \\
\hline & & & 63.017 & 22.563 & 2.988 & 10.032 & & & \\
\hline \multirow{2}{*}{ Q-14 } & \multirow{2}{*}{ Playa } & \multirow{2}{*}{$\begin{array}{l}\text { Mudstone/ } \\
\text { siltstone }\end{array}$} & 65.255 & 22.480 & 3.136 & 9.895 & \multirow{2}{*}{83.6} & \multirow{2}{*}{1.7} & \multirow{2}{*}{14.7} \\
\hline & & & 65.011 & 20.440 & 3.217 & 9.770 & & & \\
\hline \multirow{2}{*}{ E-5 } & \multirow{2}{*}{ Lacustrine } & \multirow{2}{*}{ Sandstone } & 63.695 & 21.659 & 2.218 & 10.55 & \multirow{2}{*}{81.1} & \multirow{2}{*}{9.4} & \multirow{2}{*}{9.5} \\
\hline & & & 63.891 & 20.750 & 2.312 & 9.989 & & & \\
\hline \multirow{2}{*}{$\mathrm{K}-4$} & \multirow{2}{*}{ Fluviatile } & \multirow{2}{*}{ Sandstone } & 61.631 & 23.845 & 4.535 & 9.387 & \multirow{2}{*}{78.8} & \multirow{2}{*}{0.2} & \multirow{2}{*}{21} \\
\hline & & & 62.213 & 22.981 & 4.023 & 9.125 & & & \\
\hline \multirow{2}{*}{ CTV-4 } & \multirow{2}{*}{ Lacustrine } & \multirow{2}{*}{ Sandstone } & 65.145 & 22.361 & 2.542 & 10.251 & \multirow{2}{*}{84} & \multirow{2}{*}{1} & \multirow{2}{*}{15} \\
\hline & & & 65.112 & 23.001 & 2.523 & 10.998 & & & \\
\hline
\end{tabular}

Table 4. Microprobe analyses (\% composition) of authigenic K-feldspar (East Berlin formation, Hartford Basin).

\begin{tabular}{|c|c|c|c|c|c|c|c|c|c|}
\hline $\begin{array}{c}\text { Sample } \\
\text { No }\end{array}$ & Location & Lithology & $\mathrm{SiO}_{2}$ & $\mathrm{Al}_{2} \mathrm{O}_{3}$ & $\mathrm{Na}_{2} \mathrm{O}$ & $\mathrm{K}_{2} \mathrm{O}$ & $\begin{array}{c}\text { Average } \\
\mathrm{Ab}\end{array}$ & $\begin{array}{c}\text { Average } \\
\text { Or }\end{array}$ & $\begin{array}{c}\text { Average } \\
\text { An }\end{array}$ \\
\hline \multirow{5}{*}{ E-30 } & \multirow{5}{*}{ Playa } & \multirow{5}{*}{ Sandstone } & 64.23 & 19.53 & 0.84 & 15.4 & \multirow{5}{*}{2.7} & \multirow{5}{*}{97.2} & \multirow{5}{*}{0.1} \\
\hline & & & 64.2 & 19.64 & & 16.16 & & & \\
\hline & & & 64.15 & 19.31 & & 16.54 & & & \\
\hline & & & 64.25 & 19.8 & & 15.95 & & & \\
\hline & & & 64.45 & 19.07 & & 16.48 & & & \\
\hline \multirow{2}{*}{$X-12$} & \multirow{2}{*}{ Lacustrine } & \multirow{2}{*}{ Mudstone } & 64.29 & 19.71 & & 16 & \multirow{2}{*}{1} & \multirow{2}{*}{99} & \\
\hline & & & 63.29 & 19.96 & 1.12 & 15.64 & & & \\
\hline \multirow{2}{*}{$\mathrm{K}-4$} & \multirow{2}{*}{ Fluviatile } & \multirow{2}{*}{ Sandstone } & 64.05 & 19.25 & 0.8 & 15.9 & \multirow{2}{*}{0.9} & \multirow{2}{*}{99.1} & \\
\hline & & & 64.28 & 19.78 & & 15.94 & & & \\
\hline \multirow{4}{*}{ CTV-4 } & \multirow{4}{*}{ Lacustrine } & \multirow{4}{*}{ Sandstone } & 64.18 & 19.49 & & 16.33 & \multirow{4}{*}{0.8} & \multirow{4}{*}{99.2} & \\
\hline & & & 63.94 & 19.81 & & 16.24 & & & \\
\hline & & & 63.75 & 19.36 & & 16.88 & & & \\
\hline & & & 63.99 & 18.95 & 1.02 & 16.04 & & & \\
\hline
\end{tabular}

Table 5. Microprobe analyses of (5 composition) of detrital K-feldspar (East Berlin formation, Hartford Basin). $\mathrm{Ab}=$ albite, $\mathrm{Or}=$ orthoclase and $\mathrm{An}=$ anorthite.

\begin{tabular}{|c|c|c|c|c|c|c|c|c|}
\hline $\begin{array}{c}\text { Sample } \\
\text { No }\end{array}$ & Location & Lithology & $\mathrm{SiO}_{2}$ & $\mathrm{Al}_{2} \mathrm{O}_{3}$ & $\mathrm{Na}_{2} \mathrm{O}$ & $\mathrm{K}_{2} \mathrm{O}$ & $\begin{array}{c}\text { Average } \\
\mathrm{Ab}\end{array}$ & $\begin{array}{c}\text { Average } \\
\text { Or }\end{array}$ \\
\hline \multirow{2}{*}{ E-30 } & \multirow{2}{*}{ Playa } & \multirow{2}{*}{ Sandstone } & 64.066 & 19.231 & 0.492 & 14.975 & \multirow{2}{*}{4.4} & \multirow{2}{*}{95.6} \\
\hline & & & 64.122 & 19.640 & 0.349 & 16.16 & & \\
\hline \multirow{2}{*}{$\mathrm{X}-12$} & \multirow{2}{*}{ Lacustrine } & \multirow{2}{*}{$\begin{array}{l}\text { Mudstone } \\
\text { siltstone }\end{array}$} & 63.965 & 18.793 & 0.927 & 14.288 & \multirow{2}{*}{9} & \multirow{2}{*}{91} \\
\hline & & & 63.006 & 18.76 & 0.819 & 15.001 & & \\
\hline \multirow{2}{*}{ K-4 } & \multirow{2}{*}{ Fluviatile } & \multirow{2}{*}{ Sandstone } & 64.174 & 18.711 & 0.688 & 15.836 & \multirow{2}{*}{6.2} & \multirow{2}{*}{93.8} \\
\hline & & & 64.218 & 18.178 & 0.544 & 15.114 & & \\
\hline \multirow{2}{*}{ CTV-4 } & \multirow{2}{*}{ Lacustrine } & \multirow{2}{*}{ Sandstone } & 62.548 & 18.754 & 1.03 & 15.549 & \multirow{2}{*}{6.9} & \multirow{2}{*}{93.1} \\
\hline & & & 62.762 & 18.998 & 1.097 & 15.56 & & \\
\hline
\end{tabular}

Microprobe studies in carbon coated polished sections not allowed to differentiate authigenic albite from detrital plagioclase feldpspar, and also authigenic K-feldspar from detrital $\mathrm{K}$-feldspar. However, ternary plot based on pure anorthite $(\mathrm{An})$, pure albite $(\mathrm{Ab})$ and pure 
orthoclase (Or) end member showed that authigenic albite plotted near the apices of Ab (Figure 8a), whereas detrital plagioclase plotted away from the Ab apices (Figure 8b).

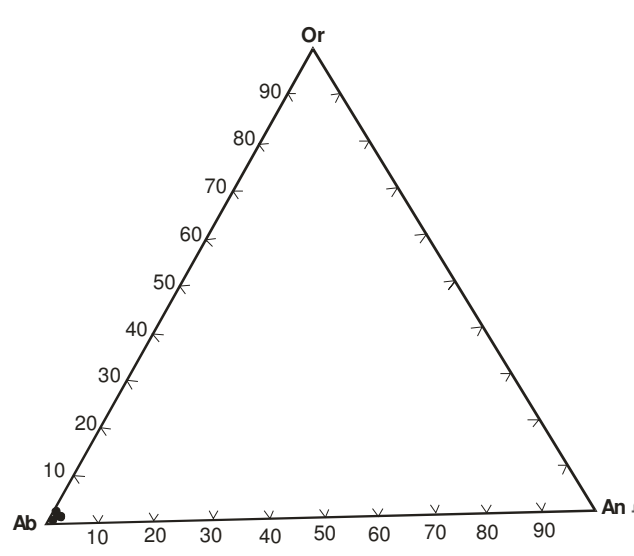

(a)

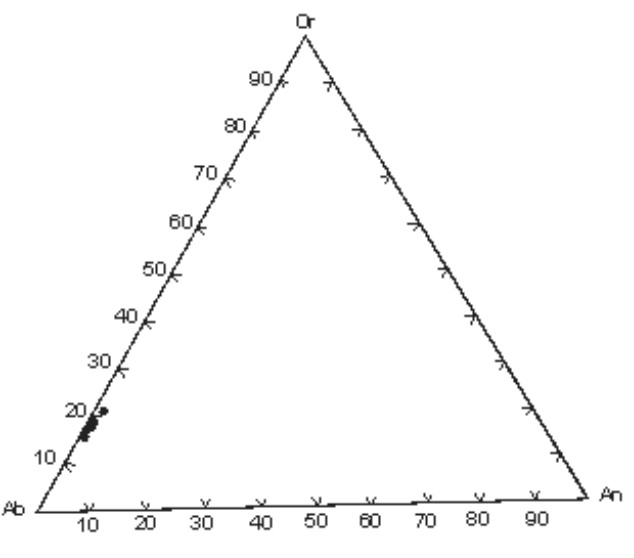

(b)

Figure 8. (a) Ternary plot for authigenic K-feldspar based upon anorthite (An), albite (Ab) and orthoclase (Or) end members. (b) Ternary plot for detrital K-feldspar based upon anorthite, albite and orthoclase end members.

Authigenic K-feldspar crystals are plotted near the apices of Or (Figure 9a), whereas the detrital K-feldspar plotted away from the apices of Or (Figure 9b). The distribution of authigenic albite and authigenic K-feldspar near the apices of $\mathrm{Ab}$ and Or indicate their authigenic origin. The distribution of the detrital plagioclase feldspar and detrital K-feldspar away from the $\mathrm{Ab}$ and Or apices indicated their detrital origin. Microprobe analyses of authigenic K-feldspar and detrital K-feldspar and authigenic albite and detrital plagioclase feldspar are given in Tables 2-5.

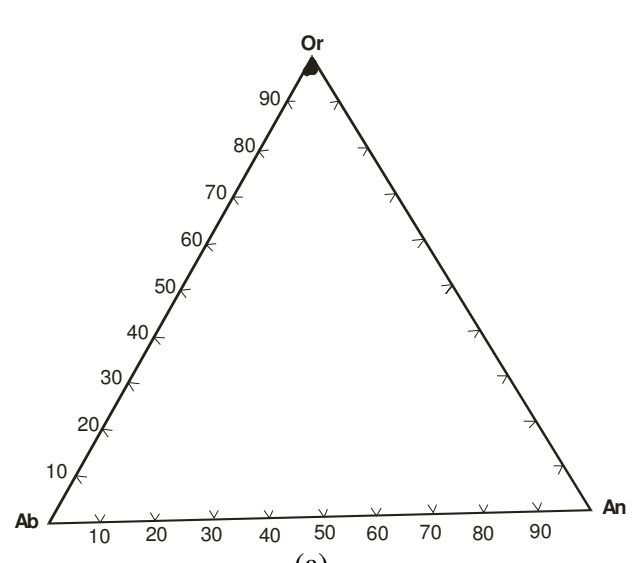

(a)

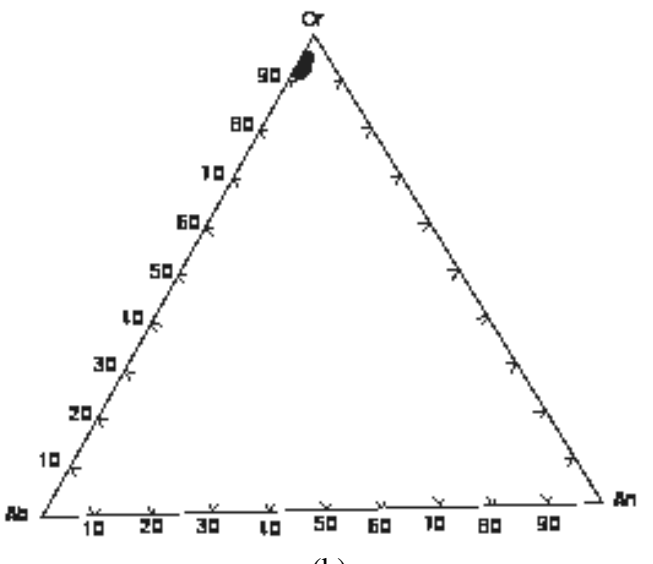

(b)

Figure 9. (a) Ternary plot for authigenic albite based upon anorthite, albite and orthoclase end members. (b) Ternary plot for detrital plagioclase based upon anorthite, albite and orthoclase end members.

Bull. Chem. Soc. Ethiop. 2007, 21(1) 
Authigenesis of quartz. Petrographic microscope and SEM studies revealed the presence of euhedral crystals and overgrowths in the muddy, silty and sandy facies. Quartz overgrowths and crystals are less common compared to authigenic feldspar overgrowths and crystals. The authgenic quartz crystals range from 1 to $5 \mu \mathrm{m}$ across in the silty and muddy facies, whereas the authigenic quartz crystals in the sandy facies range from $10 \mu \mathrm{m}$ to $100 \mu \mathrm{m}$. The possible sources for quartz authigenesis include: (i) dissolution of unstable framework grains (feldspar and ferromagnesian minerals), and (ii) mass transfer of silicon ions into the pore water from the interbedded fine-grained sediments. Part of the silica budget might have come from the underlying and overlying interbedded fine-grained sediments through compaction and diffusion [12]. In subsiding rift basins, dissolved material moves from areas of high concentration to areas of low concentration. Many workers [12, 31, 32, 33] invoke fine-grained sediments as a source for silica cementation. Quartz overgrowths abundantly distributed in sandy facies comparing to silty and muddy facies.

Circular and elliptical, aqueous and petroleum fluid inclusions in the late stage quartz crystals yielded temperatures of entrapment from 110 to $130{ }^{\circ} \mathrm{C}$ (Figure 10). Quartz crystals contain both aqueous and hydrocarbon inclusions indicating that quartz authigenesis continued during oil emplacement.

The possible sources for the silicon ions might be: (1) the dissolution of ferromagnesian minerals, (2) percolation of topography and gravity-driven meteoric silicon-rich pore water, (3) dissolution of feldspar, and (4) pore-water and mass exchange from the interbedded mudrocks, siltstones and shales [7]. Quartz overgrowths start as numerous minute, incipient pyramidal prisms that developed into well-developed crystal faces. Continued merging of faces to develop euhedral crystals indicates that the physicochemical conditions, i.e. pore water super-saturation with silicon ions, pore space and time were adequate [7].

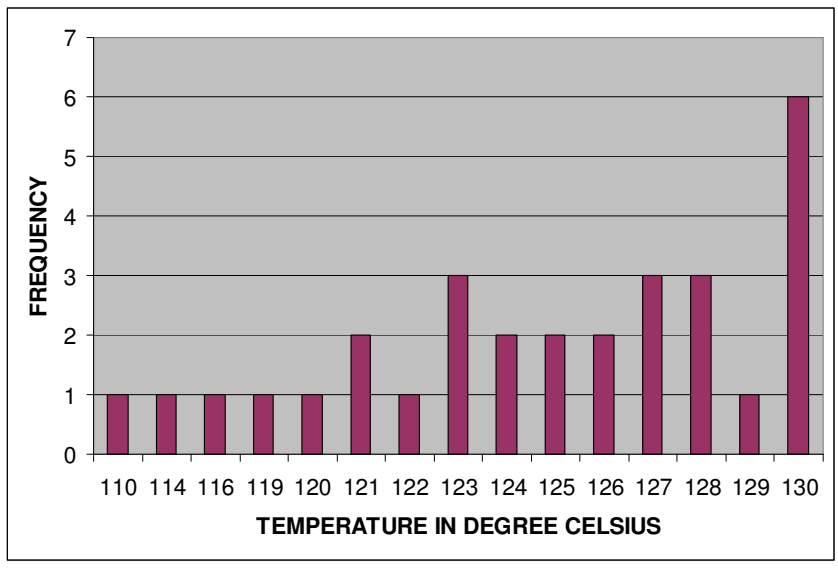

Figure 10. Fluid inclusion data for East Berlin formation.

Carbonate cementation. Carbonate cementation took place in early and late stage diagenesis. The early stage concretionary carbonates (calcrete) are characterized by their non-replacive simple pore-filling nature. Precipitation of iron-rich carbonate in the fermentation zone and ironpoor carbonate precipitation in the sulphate reduction zone is well documented [5]. 
Table 6. Microprobe analyses (\% composition) of dolomite and ferroan dolomite cements (East Berlin formation).

\begin{tabular}{|c|c|c|c|c|c|c|c|}
\hline Sample No & Location & Sample type & $\mathrm{SiO}_{2}$ & $\mathrm{Fe}_{2} \mathrm{O}_{3}$ & $\mathrm{CaO}$ & $\mathrm{MgO}$ & $\mathrm{MnO}$ \\
\hline \multirow{6}{*}{ E-30 } & \multirow{6}{*}{ Playa } & \multirow{6}{*}{ Sandstone } & 1.059 & 8.404 & 27.68 & 16.253 & \\
\hline & & & 0.539 & 11.062 & 26.94 & 14.566 & \\
\hline & & & 0.61 & 12.919 & 26.661 & 12.662 & \\
\hline & & & 0.871 & 10.231 & 28.172 & 14.247 & \\
\hline & & & 0.313 & 8.142 & 29.671 & 16.772 & \\
\hline & & & & 4.944 & 31.363 & 11.501 & 1.28 \\
\hline \multirow{8}{*}{$X-14$} & \multirow{8}{*}{ Lacustrine } & \multirow{8}{*}{ Siltstone } & 0.671 & 5.742 & 26.524 & 18.332 & 2.708 \\
\hline & & & 1.538 & 2.538 & 29.101 & 15.939 & 0.699 \\
\hline & & & & 3.395 & 31.742 & 19.039 & 0.851 \\
\hline & & & 1.266 & 2.972 & 30.454 & 16.176 & 0.917 \\
\hline & & & 0.34 & & 32.317 & 22.37 & \\
\hline & & & 0.342 & & 31.402 & 21.209 & \\
\hline & & & 0.464 & & 31.354 & 21.238 & \\
\hline & & & 0.515 & & 31.68 & 19.829 & \\
\hline \multirow{3}{*}{$X-12$} & \multirow{3}{*}{ Lacustrine } & \multirow{3}{*}{ Mudstone } & & 8.579 & 24.231 & 15.946 & \\
\hline & & & & 20.306 & 25.753 & 16.921 & \\
\hline & & & & 19.327 & 27.955 & 17.367 & \\
\hline \multirow{8}{*}{ SH-1 } & \multirow{8}{*}{ Lacustrine } & \multirow{8}{*}{ Shale } & & 2.412 & 27.806 & 16.764 & \\
\hline & & & 0.888 & 2.386 & 27.023 & 17.253 & \\
\hline & & & 1.947 & 2.034 & 26.169 & 17.56 & \\
\hline & & & 1.022 & 2.37 & 26.374 & 16.503 & \\
\hline & & & 0.86 & 3.013 & 28.539 & 15.22 & \\
\hline & & & 0.498 & 3.107 & 28.309 & 16.544 & \\
\hline & & & 0.727 & 3.454 & 27.39 & 15.851 & \\
\hline & & & 0.369 & 2.003 & 28.862 & 18.315 & \\
\hline \multirow{10}{*}{$\mathrm{SH}-2$} & \multirow{10}{*}{ Lacustrine } & \multirow{10}{*}{ Shale } & & 5.196 & 30.006 & 16.931 & \\
\hline & & & 4.396 & 4.59 & 27.129 & 15.448 & \\
\hline & & & 0.698 & 4.217 & 27.099 & 16.806 & \\
\hline & & & 0.632 & 5.791 & 28.626 & 16.809 & \\
\hline & & & 1.992 & 0.783 & 28.428 & 16.829 & \\
\hline & & & 0.415 & 5.274 & 29.204 & 15.973 & \\
\hline & & & & 0.543 & 28.883 & 18.628 & \\
\hline & & & 0.449 & & 28.6 & 18.013 & \\
\hline & & & & & 29.287 & 17.287 & \\
\hline & & & 0.55 & 2.336 & 27.736 & 17.071 & \\
\hline \multirow{7}{*}{ CTV-4 } & \multirow{7}{*}{ Lacustrine } & \multirow{7}{*}{ Sandstone } & & 8.44 & 27.37 & 15.109 & \\
\hline & & & 0.367 & 12.557 & 24.097 & 10.522 & \\
\hline & & & & 12.891 & 25.352 & 10.753 & \\
\hline & & & & 12.314 & 25.314 & 11.227 & 0.473 \\
\hline & & & & 10.742 & 25.533 & 12.258 & 0.758 \\
\hline & & & & 9.161 & 27.156 & 12.87 & 0.758 \\
\hline & & & & 1.452 & 48.057 & 4.444 & 0.864 \\
\hline
\end{tabular}

Bull. Chem. Soc. Ethiop. 2007, 21(1) 
Table 7. Microprobe analyses (\% composition) of calcite cements (East Berlin formation, Hartford Basin).

\begin{tabular}{|c|c|c|c|c|c|c|c|}
\hline Sample No & Location & Sample type & $\mathrm{SiO}_{2}$ & $\mathrm{Fe}_{2} \mathrm{O}_{3}$ & $\mathrm{CaO}$ & $\mathrm{MgO}$ & $\mathrm{MnO}$ \\
\hline \multirow{4}{*}{ CTV-6 } & \multirow{4}{*}{ Fluviatile } & \multirow{4}{*}{ Sandstone } & 0.903 & & 50.73 & 0.476 & 0.918 \\
\hline & & & 0.825 & 0.472 & 50.818 & & \\
\hline & & & 0.337 & & 55.301 & & 1.635 \\
\hline & & & 0.217 & & 52.311 & & \\
\hline \multirow{5}{*}{ K-4 } & \multirow{5}{*}{ Fluviatile } & \multirow{5}{*}{$\begin{array}{l}\text { Siltstone/ } \\
\text { siltstone }\end{array}$} & & & 57.496 & & \\
\hline & & & & & 59.917 & & \\
\hline & & & & & 57.732 & & \\
\hline & & & & & 58.387 & & \\
\hline & & & & & 56.651 & & \\
\hline
\end{tabular}

Late stage replacive carbonate cements extensively cemented the fluviatile, playa and lacustrine sediments. Varieties of carbonate cements (calcite, ferroan calcite, dolomite, ferroan dolomite and ankerite) (Figures 6e and f) occur in the fluviatile, playa and lacustrine sediments. The variation in carbonate cements depends upon the availability of metallic cations, due to the breakdown of various minerals in different diagenetic zones [4]. Dolomite and ferroan dolomite widely distributed in playa and lacustrine sandstones and fine-grained sediment, whereas calcite cement dominated fluvatile sandstone and fine-grained sediments.

The lacustrine mudstones, siltstones and sandstones extensively cemented by dolomite and ferroan dolomite. Calcite cements are abundantly distributed in the fluviatile sediments (Figure 6e). Volumetrically, dolomite is the most extensively distributed carbonate cement in the lacustrine and playa silty, muddy and sandy facies. It is characterized by both euhedral and microcrystalline forms. The abundance of dolomite cement in the lacustrine and playa settings reflects the concentration of magnesium and/or contraction of the saline lake through evaporation to elevate the $\mathrm{Mg} / \mathrm{Ca}$ ratios.

Mechanical compaction of fine-grained sediments might have released ions into the sandy facies for the authigenesis of carbonate cements. The abundance of carbonate crystals in the sandy facies near the sandstone-mudstone and sandstone-siltstone conatacts (Figures 6e and f) indicates mass transfer (pore water and ions) from the fine-grained sediments into the sand-rich section of the basin. The silty and muddy facies are dominated by detrital carbonate rock fragments (6f). XRF results indicate that the upper grey mudstones have $\mathrm{MgO}$ contents up to $7.02 \%$. The black shales, which are interbedded between the upper grey laminated mudstones and lower laminated grey mudstones contain $\mathrm{MgO}(13.69 \%)$, whereas the lower grey mudstones contain up to $3.97 \%$ [34]. The grey mudstones and black shales that are interbedded within the sandstone facies are possible a source of the carbonate cements in the sandy facies. The most important sources of ions for the authigenesis of carbonate cements in the fluviatile, playa and lacustrine settings included: (i) interstitial dissolution of unstable minerals, (ii) mass transfer of ions in pore waters from interbedded siltstones, mudstones and shales, and (iii) calcrete $\left(\mathrm{CaCo}_{3}\right)$ in fluvatile flood plain sediments most likely source of calcite cementation in the sandy facies near the calcrete horizons.

Microprobe analyses of dolomite in the lacustrine muddy and silty facies revealed an average $\mathrm{Mg} / \mathrm{Ca}$ ratio of 0.649 , whilst the dolomite cement in the sandy facies have an average $\mathrm{Mg} / \mathrm{Ca}$ ratio of 0.676 . Microprobe analyses on ferroan dolomite and ankerite cement in the finegrained lacustrine sediments (siltstones and mudstones) have average ratio of $\mathrm{Fe} / \mathrm{Ca} 0.207$ and $\mathrm{Mg} / \mathrm{Ca}$ ratio of 0.561 , whilst the ferroan dolomite cements in the sandy facies revealed in average $\mathrm{Fe} / \mathrm{Ca}$ ratio of 0.303 and $\mathrm{Mg} / \mathrm{Ca}$ ratio of 0.360 . Microprobe analyses on ferroan dolomite in the playa sandstone revealed an average $\mathrm{Fe} / \mathrm{Ca}$ ratio of $0.298, \mathrm{Mg} / \mathrm{Ca}$ ratio of 0.502 and $\mathrm{Mn} / \mathrm{Ca}$ ratio of 0.010 . Microprobe analyses on ankerite cement in the playa sandstones

Bull. Chem. Soc. Ethiop. 2007, 21(1) 
revealed an average $\mathrm{Fe} / \mathrm{Ca}$ ratio of $0.410, \mathrm{Mg} / \mathrm{Ca}$ ratio of 0.479 and $\mathrm{Mn} / \mathrm{Ca}$ ratio of 0.029 . Microprobe analyses of carbonate cements are given in Tables 6 and 7.

Table 8. Detrital and authigenic minerals abundance in fluvatile sediments, East Berlin formation.

\begin{tabular}{|c|c|c|c|c|c|}
\hline Detrital minerals & Abundance & Detrital minerals & Abundance & Detrital minerals & Abundance \\
\hline Quartz & $\mathrm{xx}$ & Quartz & $\mathrm{xx}$ & Quartz & $\mathrm{xx}$ \\
\hline Feldspar & $\mathrm{xxxx}$ & Feldspar & $\mathrm{xxxx}$ & Feldspar & $\mathrm{xxx}$ \\
\hline Rock fragments & $\mathrm{x}$ & Rock fragments & $\mathrm{x}$ & Rock fragments & $\mathrm{x}$ \\
\hline Detrital clay & $\mathrm{xx}$ & Detrital clay & $\mathrm{xx}$ & Detrital clay & $\mathrm{xxx}$ \\
\hline Micas & $\mathrm{x}$ & Micas & $\mathrm{xx}$ & Micas & $\mathrm{xx}$ \\
\hline Heavy minerals & $\mathrm{x}$ & Heavy minerals & $\mathrm{x}$ & Heavy minerals & $\mathrm{x}$ \\
\hline Sandstone & & Siltstone & & Mudstone & \\
\hline $\begin{array}{l}\text { Authigenic } \\
\text { minerals }\end{array}$ & Abundance & \begin{tabular}{|l} 
Authigenic \\
minerals
\end{tabular} & Abundance & \begin{tabular}{|l}
$\begin{array}{l}\text { Authigenic } \\
\text { minerals }\end{array}$ \\
\end{tabular} & Abundance \\
\hline Concretion & $\mathrm{xx}$ & Concretion & $\mathrm{x}$ & Concretion & $\mathrm{x}$ \\
\hline Illite-smectite & $\mathrm{xx}$ & Illite-smectite & $\mathrm{xx}$ & Illite-smectite & $\mathrm{x}$ \\
\hline $\begin{array}{l}\text { Feldspar } \\
\text { overgrowths }\end{array}$ & $\mathrm{xxxx}$ & $\begin{array}{l}\text { Feldspar } \\
\text { overgrowths }\end{array}$ & $\mathrm{xxx}$ & \begin{tabular}{|l}
$\begin{array}{l}\text { Feldspar } \\
\text { overgrowths }\end{array}$ \\
\end{tabular} & $\mathrm{xx}$ \\
\hline $\begin{array}{l}\text { Quartz } \\
\text { overgrowths }\end{array}$ & $\mathrm{xxx}$ & \begin{tabular}{|l} 
Quartz \\
overgrowths
\end{tabular} & $\mathrm{xx}$ & \begin{tabular}{|l} 
Quartz \\
overgrowths
\end{tabular} & $\mathrm{x}$ \\
\hline Caclite & $\mathrm{xx}$ & Caclite & $\mathrm{xx}$ & Caclite & $\mathrm{xx}$ \\
\hline Kaolinite & $\mathrm{xx}$ & Kaolinite & $\mathrm{x}$ & Kaolinite & $\mathrm{x}$ \\
\hline Hematite & $\mathrm{xx}$ & Hematite & $\mathrm{xx}$ & Hematite & $\mathrm{x}$ \\
\hline Illite & $\mathrm{xx}$ & Illite & $\mathrm{x}$ & Illite & $\mathrm{x}$ \\
\hline Sandstone & & Siltstone & & Mudstone & \\
\hline $\begin{array}{l}\text { Detrital } \\
\text { minerals }\end{array}$ & Abundance & $\begin{array}{c}\text { Authigenic } \\
\text { minerals }\end{array}$ & Abundance & & \\
\hline Feldspar & $\mathrm{xxx}$ & Concretion & & & \\
\hline $\begin{array}{l}\text { Rock } \\
\text { fragments }\end{array}$ & $\mathrm{xx}$ & Illite-smectite & $\mathrm{x}$ & & \\
\hline Detrital clay & $\mathrm{xxxx}$ & $\begin{array}{l}\text { Feldspar } \\
\text { overgrowths }\end{array}$ & & & \\
\hline Micas & $\mathrm{xx}$ & $\begin{array}{l}\text { Quartz } \\
\text { overgrowths }\end{array}$ & & & \\
\hline $\begin{array}{l}\text { Heavy } \\
\text { minerals }\end{array}$ & $\mathrm{x}$ & Caclite & $\mathrm{x}$ & & \\
\hline \multirow{4}{*}{\multicolumn{2}{|c|}{ Shale }} & Kaolinite & & & \\
\hline & & Hematite & $\mathrm{x}$ & & \\
\hline & & Illite & $\mathrm{x}$ & & \\
\hline & & Shale & & & \\
\hline
\end{tabular}

Key: $\mathrm{xxxx}=$ major, $\mathrm{xxx}=$ moderate, $\mathrm{xx}=$ minor, $\mathrm{x}=$ very minor. 
Table 9. Detrital and authigenic minerals abundance in lacustrine sediments, East Berlin formation

\begin{tabular}{|l|l|l|l|l|l|}
\hline $\begin{array}{l}\text { Detrital } \\
\text { minerals }\end{array}$ & Abundance & $\begin{array}{l}\text { Detrital } \\
\text { minerals }\end{array}$ & Abundance & $\begin{array}{l}\text { Detrital } \\
\text { minerals }\end{array}$ & Abundance \\
\hline Quartz & $\mathrm{xx}$ & Quartz & $\mathrm{xx}$ & Quartz & $\mathrm{xx}$ \\
\hline Feldspar & $\mathrm{xxxx}$ & Feldspar & $\mathrm{xx}$ & Feldspar & $\mathrm{x}$ \\
\hline $\begin{array}{l}\text { Rock } \\
\text { fragments }\end{array}$ & $\mathrm{x}$ & Rock fragments & $\mathrm{x}$ & $\begin{array}{l}\text { Rock } \\
\text { fragments }\end{array}$ & $\mathrm{x}$ \\
\hline Detrital clay & $\mathrm{xx}$ & Detrital clay & $\mathrm{xx}$ & Detrital clay & $\mathrm{xx}$ \\
\hline Micas & $\mathrm{x}$ & Micas & $\mathrm{x}$ & Micas & $\mathrm{xx}$ \\
\hline $\begin{array}{l}\text { Heavy } \\
\text { minerals }\end{array}$ & $\mathrm{x}$ & Heavy minerals & $\mathrm{x}$ & $\begin{array}{l}\text { Heavy } \\
\text { minerals }\end{array}$ & $\mathrm{x}$ \\
\hline \begin{tabular}{l} 
Sandstone \\
\multicolumn{7}{|l|}{ Siltstone } & Mudstone
\end{tabular} \\
\hline
\end{tabular}

\begin{tabular}{|c|c|c|c|c|c|}
\hline $\begin{array}{c}\text { Authigenic } \\
\text { minerals }\end{array}$ & Abundance & $\begin{array}{l}\text { Authigenic } \\
\text { minerals }\end{array}$ & Abundance & $\begin{array}{c}\text { Authigenic } \\
\text { minerals }\end{array}$ & Abundance \\
\hline Pyrite & XX & Pyrite & $\mathrm{X}$ & Pyrite & $\mathrm{X}$ \\
\hline $\begin{array}{l}\text { Illite- } \\
\text { smectite }\end{array}$ & $\mathrm{xxx}$ & Illite-smectite & $\mathrm{xx}$ & Illite-smectite & $\mathrm{x}$ \\
\hline $\begin{array}{l}\text { Feldspar } \\
\text { overgrowths }\end{array}$ & $\mathrm{XXXX}$ & $\begin{array}{l}\text { Feldspar } \\
\text { overgrowths }\end{array}$ & $\mathrm{xx}$ & $\begin{array}{l}\text { Feldspar } \\
\text { overgrowths }\end{array}$ & $\mathrm{x}$ \\
\hline $\begin{array}{l}\text { Quartz } \\
\text { overgrowths }\end{array}$ & $\mathrm{XXX}$ & $\begin{array}{l}\text { Quartz } \\
\text { overgrowths }\end{array}$ & $\mathrm{xx}$ & $\begin{array}{l}\text { Quartz } \\
\text { overgrowths }\end{array}$ & $\mathrm{x}$ \\
\hline Caclite & $\mathrm{x}$ & Caclite & $\mathrm{x}$ & Caclite & $\mathrm{x}$ \\
\hline Dolomite & $\operatorname{xxxx}$ & Dolomite & $\mathrm{XxX}$ & Dolomite & $\mathrm{XxX}$ \\
\hline Kaolinite & $\mathrm{xx}$ & Kaolinite & $\mathrm{x}$ & Kaolinite & \\
\hline $\begin{array}{l}\text { Smectit- } \\
\text { chlorite }\end{array}$ & $\mathrm{XX}$ & Smectit-chlorite & $\mathrm{x}$ & $\begin{array}{l}\text { Smectit- } \\
\text { chlorite }\end{array}$ & $\mathrm{x}$ \\
\hline Hematite & $\mathrm{xx}$ & Hematite & $\mathrm{xx}$ & Hematite & $\mathrm{x}$ \\
\hline Chlorite & $\mathrm{xx}$ & Chlorite & $\mathrm{x}$ & Chlorite & $\mathrm{x}$ \\
\hline
\end{tabular}

\begin{tabular}{|c|c|c|c|}
\hline $\begin{array}{l}\text { Detrital } \\
\text { minerals }\end{array}$ & Abundance & $\begin{array}{c}\text { Authigenic } \\
\text { minerals }\end{array}$ & Abundance \\
\hline Quartz & $\mathrm{X}$ & & \\
\hline Feldspar & $\mathrm{x}$ & Pyrite & \\
\hline $\begin{array}{l}\text { Rock } \\
\text { fragments }\end{array}$ & $\mathrm{x}$ & Illite-smectite & $\mathrm{x}$ \\
\hline Detrital clay & $\operatorname{xxxx}$ & $\begin{array}{l}\text { Feldspar } \\
\text { overgrowths }\end{array}$ & \\
\hline Micas & $\mathrm{xx}$ & $\begin{array}{l}\text { Quartz } \\
\text { overgrowths }\end{array}$ & \\
\hline $\begin{array}{l}\text { Heavy } \\
\text { minerals }\end{array}$ & $\mathrm{x}$ & Caclite & $\mathrm{x}$ \\
\hline \multirow{5}{*}{\multicolumn{2}{|c|}{ Shale }} & Dolomite & $\mathrm{x}$ \\
\hline & & Kaolinite & \\
\hline & & Smectit-chlorite & \\
\hline & & Hematite & $\mathrm{x}$ \\
\hline & & Chlorite & \\
\hline
\end{tabular}

Key: $\mathrm{xxxx}=$ major, $\mathrm{xxx}=$ moderate, $\mathrm{xx}=$ minor, $\mathrm{x}=$ very minor .

Bull. Chem. Soc. Ethiop. 2007, 21(1) 
Table 10. Detrital and authigenic minerals abundance in playa sediments, East Berlin formation.

\begin{tabular}{|c|c|c|c|c|c|}
\hline Detrital minerals & Abundance & $\begin{array}{l}\text { Detrital } \\
\text { minerals }\end{array}$ & Abundance & $\begin{array}{l}\text { Detrital } \\
\text { minerals }\end{array}$ & Abundance \\
\hline Quartz & $\mathrm{xx}$ & Quartz & $\mathrm{x}$ & Quartz & $\mathrm{x}$ \\
\hline Feldspar & $\mathrm{XXXX}$ & Feldspar & $\mathrm{XXX}$ & Feldspar & $\mathrm{XX}$ \\
\hline Rock fragments & $\mathrm{x}$ & $\begin{array}{l}\text { Rock } \\
\text { fragments }\end{array}$ & $\mathrm{x}$ & $\begin{array}{l}\text { Rock } \\
\text { fragments }\end{array}$ & $\mathrm{x}$ \\
\hline Detrital clay & $\mathrm{XX}$ & Detrital clay & $\mathrm{XX}$ & Detrital clay & $\mathrm{XxX}$ \\
\hline Micas & $\mathrm{x}$ & Micas & $\mathrm{xx}$ & Micas & $\mathrm{xx}$ \\
\hline Heavy minerals & $\mathrm{x}$ & $\begin{array}{l}\text { Heavy } \\
\text { minerals }\end{array}$ & $\mathrm{x}$ & $\begin{array}{l}\text { Heavy } \\
\text { minerals }\end{array}$ & $\mathrm{x}$ \\
\hline \multicolumn{2}{|l|}{ Sandstone } & \multicolumn{2}{|l|}{ Siltstone } & \multicolumn{2}{|l|}{ Mudstone } \\
\hline $\begin{array}{l}\text { Authigenic } \\
\text { minerals }\end{array}$ & Abundance & $\begin{array}{c}\text { Authigenic } \\
\text { minerals }\end{array}$ & Abundance & $\begin{array}{c}\text { Authigenic } \\
\text { minerals }\end{array}$ & Abundance \\
\hline Concretion & $\mathrm{XX}$ & Concretion & $\mathrm{x}$ & Concretion & $\mathrm{x}$ \\
\hline Illite-smectite & $\mathrm{xx}$ & Illite-smectite & $\mathrm{xx}$ & $\begin{array}{l}\text { Illite- } \\
\text { smectite }\end{array}$ & $\mathrm{x}$ \\
\hline $\begin{array}{l}\text { Feldspar } \\
\text { overgrowths }\end{array}$ & $\operatorname{xxxx}$ & $\begin{array}{l}\text { Feldspar } \\
\text { overgrowths }\end{array}$ & $\mathrm{xxx}$ & $\begin{array}{l}\text { Feldspar } \\
\text { overgrowths }\end{array}$ & $\mathrm{xx}$ \\
\hline $\begin{array}{l}\text { Quartz } \\
\text { overgrowths }\end{array}$ & $\mathrm{xxx}$ & $\begin{array}{l}\text { Quartz } \\
\text { overgrowths }\end{array}$ & $\mathrm{xx}$ & $\begin{array}{l}\text { Quartz } \\
\text { overgrowths }\end{array}$ & $\mathrm{x}$ \\
\hline Kaolinite & $\mathrm{XX}$ & Kaolinite & $\mathrm{X}$ & Kaolinite & $\mathrm{X}$ \\
\hline Hematite & $\mathrm{xx}$ & Hematite & $\mathrm{xx}$ & Hematite & $\mathrm{X}$ \\
\hline Illite & $\mathrm{xx}$ & Illite & $\mathrm{X}$ & Illite & $\mathrm{X}$ \\
\hline \multicolumn{2}{|l|}{ Sandstone } & \multicolumn{2}{|l|}{ Siltstone } & \multirow[t]{9}{*}{ Mudstone } & \\
\hline Detrital minerals & Abundance & $\begin{array}{c}\text { Authigenic } \\
\text { minerals }\end{array}$ & Abundance & & \\
\hline Feldspar & $\mathrm{X}$ & Concretion & & & \\
\hline Rock fragments & $\mathrm{x}$ & $\begin{array}{l}\text { Illite- } \\
\text { smectite }\end{array}$ & $\mathrm{x}$ & & \\
\hline Detrital clay & $\operatorname{xxxx}$ & $\begin{array}{l}\text { Feldspar } \\
\text { overgrowths }\end{array}$ & & & \\
\hline Micas & $\mathrm{xx}$ & $\begin{array}{l}\text { Quartz } \\
\text { overgrowths }\end{array}$ & & & \\
\hline Heavy minerals & $\mathrm{x}$ & Kaolinite & & & \\
\hline \multirow{2}{*}{\multicolumn{2}{|c|}{ Shale }} & Hematite & $\mathrm{X}$ & & \\
\hline & & Illite & $\mathrm{X}$ & & \\
\hline
\end{tabular}

Key: $\mathrm{xxxx}=$ major, $\mathrm{xxx}=$ moderate, $\mathrm{xx}=$ minor, $\mathrm{x}=$ very minor.

\section{Reservoir properties}

Depositional environment, pore-water chemistry, diagenetic processes, burial and thermal history of the basin governed the porosity evolution of the studied sandstone and other clastic sediments. The fluviatile and lacustrine sandstones are more porous than the fine-grained clastic sediments. Carbonic acid is formed when rain water react with carbon dioxide in the air. Secondary porosity was generated due to the percolation of gravity-driven acidic meteoric water during early diagenesis. Circulation of meteoric water in the diagenetic environment facilitated the dissolution of unstable grains to generate secondary porosity. In rift basins, gravity-driven acidic meteoric water flow can penetrate at least several kilometers in the sedimentary basin. In late diagenesis, mature source rocks and clay minerals transformation released $\mathrm{CO}_{2}$, which

Bull. Chem. Soc. Ethiop. 2007, 21(1) 
facilitated the entry of acidic pore-water into the diagenetic environment to dissolve the carbonate cements and unstable framework grains to generate secondary porosity (Figure 7a and b). In the East Berlin formation, secondary porosity was generated before oil migration, as evidenced by the presence of bitumen in some of the secondary porosity (Figure 7c and d).

Mechanical compaction, grain-coatings and pore-lining and pore-filling (clay minerals, feldspar overgrowths, quartz overgrowths and carbonate cements) are major factors in reducing intergranular porosity. The porosity in the fine-grained clastic sediments is highly diminished by mechanical compaction and cementation. Some of the studied interbedded siltstones and mudstones in the East Berlin formation exhibited fair to good porosity up to $20 \%$ (Figures 6b, $7 \mathrm{a}$ and $\mathrm{f}$ ), whereas such pores have poor interconnectedness. The pore throats of such rocks are too small for oil to pass due to high capillary pressure [35]. Permeability is controlled by many factors such as effective porosity of the rock, geometry of pores, tortuosity, size of the throat between the pores, the capillary force between the rock and pressure gradient and fluid flow [36]. The sandy facies is the most porous and permeable potential reservoir for oil and gas, whereas the muddy and silty facies are possible gas reservoir.

The presence of interbedded siltstones, mudstones and shales in the sandstone facies accounts for porosity loss in sandstone facies. The sandy facies near sandstone-siltstone and sandstone-mudstone contacts exhibited porosity loss due to extensive quartz crystals precipitation.

\section{Interpretation}

The diagenetic processes that took place in the sandy facies also took place in the muddy and silty facies. Grain-coating clay/hematite, pore-filling and pore-lining clays, quartz overgrowths, feldspar overgrowths, carbonate cements are observed in the sandstone, siltstone and mudstone facies. The distribution of authigenic minerals varies in the sandy, silty and muddy facies. This might be related to distribution of permeability and the supersaturation of the pore water with respect to silicon, aluminium, potassium, sodium, calcium, magnesium and iron ions. The abundance of authigenic minerals in decreasing order include: sandstone $>$ siltstone $>$ mudstone $>$ shale. The abundance of authigenic minerals in the sandstone facies might be related to the distribution of permeability, which might acted as a conduit for formation water circulation. Except minor amounts of authigenic illite-smectite and illite the shaly facies is dominated by detrital carbonate, quartz and feldspar grains.

The studied fluviatile and playa sandstones and fine-grained sediments followed red bed diagenesis, whereas the lacustrine sediments followed marine diagnesis [7]. Syn-depositional minerals variations were encountered in the depositional environments. At early stage of diagenesis, the fluvial sandstones and fine-grained sediments are dominated by mechanically infiltrated clays, pedognic mud aggregates and concretionary calcite. The playa sandstones and fine-grained sediment is dominated by concretionary dolomite, whereas the lacustrine sediments are dominated by pyrite crystals.

There are variations in clay mineralogy. Mechanically infiltrated clays are found in the fluvial sandstones and fine-grained sediments, and dominated by illite and illite-smectite. In some sandstone, siltstone and mudstone samples, primary porosity is highly reduced by infiltrated clay. In places, the authigenesis of carbonate cements, quart and feldspar overgrowths and generation of secondary porosity retarded by the abundance distribution of mechanically infiltrated clays [7, 18]. The authigenic clay minerals in the East Berlin formation are dominated by illite in the fluvial sequence and smectite-chlorite, illite-smectite in the lacustrine sandstones, siltstones and mudstones. In places, mixed-layers (illite-smectite and smectite-chlorite) in the East Berlin formation have the most marked effect on the reservoir properties, reducing porosity to zero.

Bull. Chem. Soc. Ethiop. 2007, 21(1) 
There are variations in carbonate cements in the East Berlin formation. Dolomite, ferroan dolomite and ankerite were restricted to the lacustrine sandstones, siltstones and mudstones indicating that saline alkaline conditions were suitable for precipitation these minerals [7]. Abundance of calcite found in the fluvial sandstones possibly indicates open drainage. Calcite cementation in the fluvial depositions is possibly due to abundance distribution of concretionary calcite, and the dissolution of concretionary calcite provided ions for the authigenesis of calcite. The dissolution of carbonate cements in the late stage of diagnesis produced secondary porosity, and improved the permeability and other reservoir properties of the studied sediments.

Possible sources for the dolomite, ferroan dolomite and ankerite cements are: (i) percolation of mineralized water from leaching of dolomite marble from the source area [18], (ii) concentration of $\mathrm{Mg}^{2+}$ in a closed-basin alkaline hard water lake, (iii) alteration and/or dissolution of detrital pyroxene, amphibole, biotite, magnetite, and ilmenite, (iv) dissolution of oligoclase-rich plagioclase by interstitial pore water, (v) contraction of the saline lake increased concentration of magnesium, and (vi) fluid and mass exchange from the interbedded mudrocks, siltstones, and shales [7, 12, 18, 19]. Microprobe analysis in the interbedded mudrocks confirmed the presence of extensive dolomite cements [7].

\section{CONCLUSIONS}

(1) Reconstruction of the paragenetic sequences in the studied sandstone and the interbedded mudstones and siltstones revealed the same authigenic minerals association. Paragenetic sequences in fluviatile and playa mudstones, siltstones and sandstones in the East Berlin formation indicated red bed diagenesis, whilst the diagenetic trend for the lacustrine mudstones, siltstones and sandstones is equivalent to that of marine clastic diagenesis. (2) The diagenetic processes that took place in the sandy facies also took place in the muddy and silty facies. Graincoating clay/hematite, pore-filling and pore-lining clays, quartz overgrowths, feldspar overgrowths, carbonate cements are observed in the sandstone, siltstone and mudstone facies. The distribution of authigenic minerals varies in the sandy, silty and muddy facies. This might be related to distribution of permeability and the supersaturation of the pore water with respect to silicon, aluminium, potassium, sodium, calcium, magnesium and iron ions. The abundance of authigenic minerals in decreasing order include: sandstone $>$ siltstone $>$ mudstone $>$ shale. The abundance of authigenic minerals in the sandstone facies might be related to the distribution of permeability, which might have acted as a conduit for formation water circulation. Except minor amounts of authigenic illite-smectite and illite the shaly facies is dominated by detrital carbonate, quartz and feldspar grains. (3) Part of the silica and carbonate budget for the sandy facies might have come from the interbedded mudstones, siltstones and shaly facies during compaction. The presence of authigenic quartz and carbonate crystals in the sandy facies near the mudstone-sandstone and siltstone-sandstone contacts indicates pore water and mass transfer from the fine-grained sediments. The muddy, silty and shaly facies is frequently interbedded within the East Berlin formation throughout the entire sections. In such stratigraphic settings, part of the ions for the authigenesis of quartz and carbonate cements possibly derived from the interbedded mudstones, siltstones and shales. (4) Gravity-driven acidic meteoric water in the diagenetic environment plays a significant role in leaching and circulating ions downwards in the rift basin, to precipitate different authigenic minerals in the East Berlin formation. In rift basins, gravity-driven meteoric water flow can penetrate at least several kilometers into the sedimentary basin. Pore water migration depends upon permeability distribution and pressure differentials. (5) Clay minerals existed in four forms: (i) mechanically infiltrated clay originating from percolation of mud-rich waters or illuviation of clay cutans, (ii) pedogenic mud aggregates, (iii) transformational clay, i.e. changing of mechanically infiltrated clay to authigenic clay, and 
(iv) neoformed clay directly precipitated from the pore water. There is a variation in authigenic clay mineralogy. Illite abundantly distributed in the fluvial sequence whereas smectite-chlorite, illite-smectite and chlorite dominated in the lacustrine sandstones. (6) There are variations in carbonate cements in the studied sandstone formations. Dolomite, ferroan dolomite and ankerite were restricted to the lacustrine sandstones, indicating that saline alkaline conditions were suitable for precipitation. Abundance of calcite found in the fluvial sandstones possibly indicates open drainage. (7) Oil emplacement possibly affected further precipitation of authigenic clay minerals. However, the presence of pyrite and apatite within the bitumen indicate co-precipitation during oil emplacement

\section{AKNOWLEDGEMENTS}

Earlier drafts of this manuscript were read by Dr. J. Parnell and his comments are gratefully acknowledged. Thanks are also extended to Dr. E. Gierlowski-Kordesch, and Dr. A. Ruffell. Most of the work was carried out at the School of Geosiences, the Geochemical Laboratory and the Electron Microscopy Unit, the Queen's University of Belfast. Thanks extended to the staff of these institutions. This research work was financially supported by the School of Geosciences, the Queen's University of Belfast, UK.

\section{REFERENCES}

1. Gierlowski-Kordesch, E. Rust, B.R. Sedimentology and Geochemistry of Modern and Ancient Saline Lakes, Renaut, R.W.; Last, W.M. (Eds.); SEPM Special Publication 50, Society of Economic Paleontology and Mineralogy: Tulsa, Oklahoma, USA; 1994, pp 249265.

2. Bjorlykke, K. Diagenesis, I, Development in Sedimentology, Chilingarian, G.V.; Wolf, K.H. (Eds.); Elsevier: Amsterdam; 1988; 41, pp 555-588.

3. Helmold, K.P.; Van de Kamp, P.C. Clastic Diagenesis, McDonald, D.A.; Surdum, R.C. (Eds.); AAPG Memorial 37, American Association of Petroleum Geologists: Oklahoma, USA; 1984; pp 239-276.

4. Curtis, C.D. J. Geol. Soc. London 1978, 135, 107.

5. Curtis, C.D. Petroleum Geochemistry and Exploration of Europe, Brooks, J. (Ed.); Geol. Soc. Spec. Pub. London 12, Geological Society of London: London, UK; 1983; pp 113-125.

6. Bjorlykke, K. Sediment Diagenesis, Vol. 115, Parker, A.; Sellwood, B.W. (Eds.); D. Reidel Publishing Company: Dordrecht, Holland; 1983; pp 169-213.

7. Ahmed, W. Ph.D. Thesis, The Queen's University of Belfast, Belfast; UK; 1997; p 238.

8. Power, M.C. AAPG 1967, 51, 1240.

9. Fuchtbauer, H. Sediment Diagenesis, Vol. 115, Parker, A.; Sellwood, B.W. (Eds.); D. Reidel Publishing Company: Dordrecht, Holland; 1983; pp 269-288.

10. Baker, J.C. Sedimentology 1991, 38, 819.

11. Purvis, K. Sedimentary Geology 1992, 77, 155.

12. Ahmed, W. Bull. Chem. Soc. Ethiop. 2002, 16, 37.

13. Demicco, R.V.; Gierlowski-Kordesch, E. Sedimentology 1986, 33, 107.

14. Manspeizer, W. Triassic-Jurassic Rifting: Continental Break-up and the Origin of the Atlantic Ocean and Passive Margin, Manspeizer, W. (Ed.); Part A, Elsevier: Amesterdam; 1988; pp 41-80.

15. Lorenz, J.C. Triassic-Jurassic Rift-basin Sedimentology: History and Methods, Van Nostrand Reinhold: New York; 1988; p 315.

Bull. Chem. Soc. Ethiop. 2007, 21(1) 
16. Schlische, R.W. Tectonics 1993, 12, 1026.

17. Smoot, J.P. Palaeogeography, Palaeoclimatology, Palaeoecology 1990, 84, 369.

18. Hubert, J.F.; Feshbach-Meriney, P.E.; Smith, M.A. AAPG 1992, 76, 1710.

19. Gierlowski-Kordesch, E.; Huber, P. Lake sequences in the central Hartford Basin: Newark Supergroup: State Geological and Natural History Survey: Connecticut, USA; 1995; Guidebook 7, B1-B39.

20. Sedemann, D.E. Am. J. Sci. 1989, 289, 553.

21. Hubert, J.F.; Hyde, M.G. Sedimentology 1982, 29, 457.

22. Wenk, W.J. Northeastern Geology 1990, 12, 202.

23. Ellesfsen, K.J.; Simmons, G.; Dowling, J.J.; Dehlinger, P.; Gray, N.H. Northeastern Geology 1990, 12, 231.

24. Walker, T.R. The Contental Permian in Central, West and South Europe, Falke, H. (Ed.); D. Reidel Publishing Company: Dordrecht, Holland; 1976; pp 240-282.

25. Mores, M.A.; De Ros, L. J. Sed. Petrology 1990, 60, 809.

26. Ramos, A. Geological Magazine 1995, 132, 435.

27. Orhan, H. Sedimentary Geology 1992, 77, 111.

28. Giles, M.R.; Marshall, J.D. Marine and petroleum Geology 1986, 3, 243.

29. Bjorlykke, K. Sedimentary Geology 1993, 86, 137.

30. Van de Kamp, P.C.; Leake, B.E. Chemical Geology 1996, 133, 89.

31. Schmidt, V.; McDonald, D.A. Aspect of Diagenesis, Scholle, P.A.; Schlunger, P.R. (Eds); SEPM Special Publication 26, Society of Economic Paleontology and Mineralogy: Tulsa, Oklahoma, USA; 1979, pp 175-207.

32. McBride, M.B. Environmental Chemistry of Soils. Oxford University Press: New York, 1994; $\mathrm{p} 406$.

33. Mullis, A.M. Sedimentology 1992, 39, 99.

34. April, R.H. Clay and Clay Minerals 1981, 29, 31.

35. Tucker, M.E. Sedimentary Petrology: An Introduction to the Origin of Sedimentary Rocks, 2nd ed., Blackwell Science Ltd.: London, UK; 1991; p 260.

36. Cooper, M.K.; Hunter, R.H. Mineralogical Magazine 1995, 59, 213. 